\title{
卫
}

\section{Optimizing air flow distribution in maritime refrigerated containers}

Authors: Dr. ir. Leo Lukasse, M.G. Staal

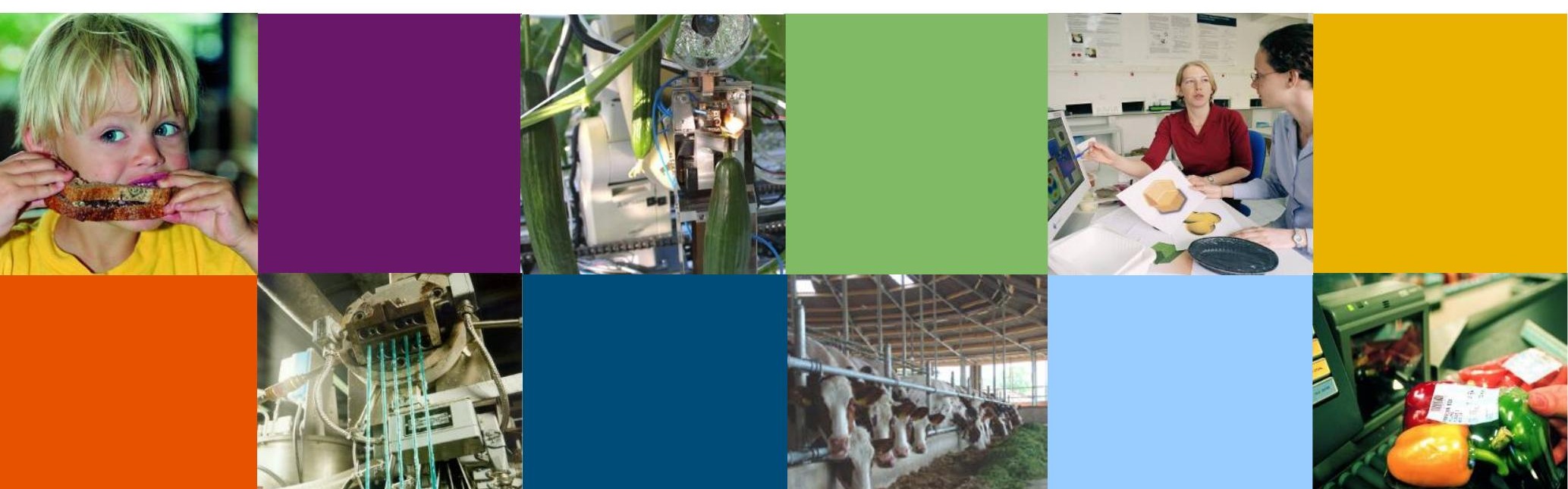




\section{Colophon}

Title

Author(s)

Number

ISBN-number

Date of publication

Confidentiality

Project number

Approved by
Optimizing air flow distribution in maritime refrigerated containers

Dr. ir. Leo Lukasse, M.G. Staal

1621

N.A.

Jan. 2016

Yes, till three years after date of publication

6239104500

Ir. Janneke de Kramer

Wageningen UR Food \& Biobased Research

P.O. Box 17

NL-6700 AA Wageningen

Tel: +31(0)317480084

E-mail: info.fbr@wur.nl

Internet: www.wur.nl

(C) Wageningen UR Food \& Biobased Research, institute within the legal entity Stichting Dienst Landbouwkundig Onderzoek

All rights reserved. No part of this publication may be reproduced, stored in a retrieval system of any nature, or transmitted, in any form or by any means, electronic, mechanical, photocopying, recording or otherwise, without the prior permission of the publisher. The publisher does not accept any liability for inaccuracies in this report.

This report can be downloaded for free from January 2019 at https://doi.org/10.18174/563043 or at www.wur.nl/wfbr (under publications). 


\begin{abstract}
In many types of maritime reefer container shipments there is a wish to reduce product temperature gradients. Temperature gradients are aggravated by poor air flow distribution. T-bars are the air ducts of reefer containers. Unfortunately most air escapes from the ducts before reaching the container door-end if no further measures are taken. The main aim of this experimental study is to design an optimised T-bar floor cover and assess its effect on cargo temperature distribution. In a series of 20 climate chamber tests it is investigated how temperature gradients are affected by evaporator fan speed, humidity setting, and four different T-bar cover designs. During the tests the container is stuffed with palletized empty cartons, with zero autonomous heat production. The results show clear positive effects of T-bar covers. The best of the four covers is non-perforated, of a trapezoidal-like shape, installed in the container with the narrowest end towards the door-end. It reduces the temperature difference between warmest and coldest measurement location directly around the cargo by nearly $50 \%$, and also accelerates temperature recovery after a power off period. It is therefore recommended to followup on these results with real transport tests, and to investigate how a simple cheap robust version of this prototype floor cover can be made available to Maersk Line customers.
\end{abstract}




\section{Content}

Abstract 3

1 Introduction $\quad 5$

1.1 Aim 6

2 Theory 7

2.1 Air flow distribution in reefer containers

2.2 Key Performance Indicators

3 Equipment specifications 10

$\begin{array}{lll}3.1 & \text { Insulated body } & 10\end{array}$

3.2 Refrigeration unit type and settings 11

3.3 Dummy load during testing 11

3.4 Logger types and positions 12

3.5 T-bar cover 15

4 Test program $\quad 24$

5 Results 26

5.1 Air flow rates 26

5.2 Temperatures 26

6 Discussion 30

7 Conclusions 33

8 Recommendations 34

9 References $\quad 35$

10 Acknowledgements 36 


\section{Introduction}

In many types of maritime reefer container shipments there is a wish for faster pulldown of product temperatures, smaller product temperature gradients in steady state, and more homogeneous temperatures during power off periods. For fast product temperature pulldown air should be guided through the cargo, while for maintaining product temperatures in non-respiring products air should be guided around the cargo. On the other hand the typical temperature gradient observed in all cargoes is from a cold unit-end to a warmer door-end. Therefore it is believed that one type of cargo-independent T-bar floor cover, guiding more air to the door-end, can help to reduce temperature differences in virtually any shipment. The cover could be a container-wide and container-long vinyl (or linoleum) flooring roll with a specific perforation pattern (Fig. 1). One would expect to benefit from few or small perforations at unit-end and many large perforations at the door-end. Such a floor cover would then be rolled out in the container prior to stuffing. It could be a one-time use accessory, like the usual product packaging materials, or maybe even reusable.

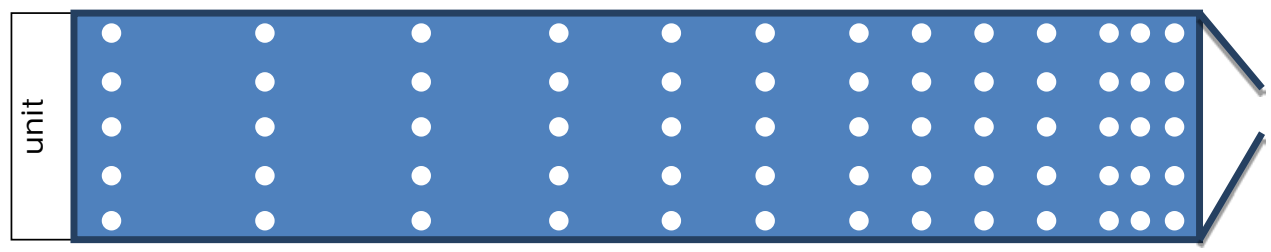

Fig. 1, sketch of a possible T-bar floor cover perforation pattern.

In 2015, in an action coordinated between Maersk Line, Wageningen UR and IBP Fraunhofer, a model simulation study was done to predict the optimal T-bar floor cover for non-respiring cargo (Norrefeldt, 2015a). Fig. 2 is a sketch of the floor cover recommended by Norrefeldt (2015a).

This study reports on a series of climate chamber tests to assess the effects of T-bar floor covers on cargo temperatures. In the tests three stages are distinguished: power off, recovery and steady

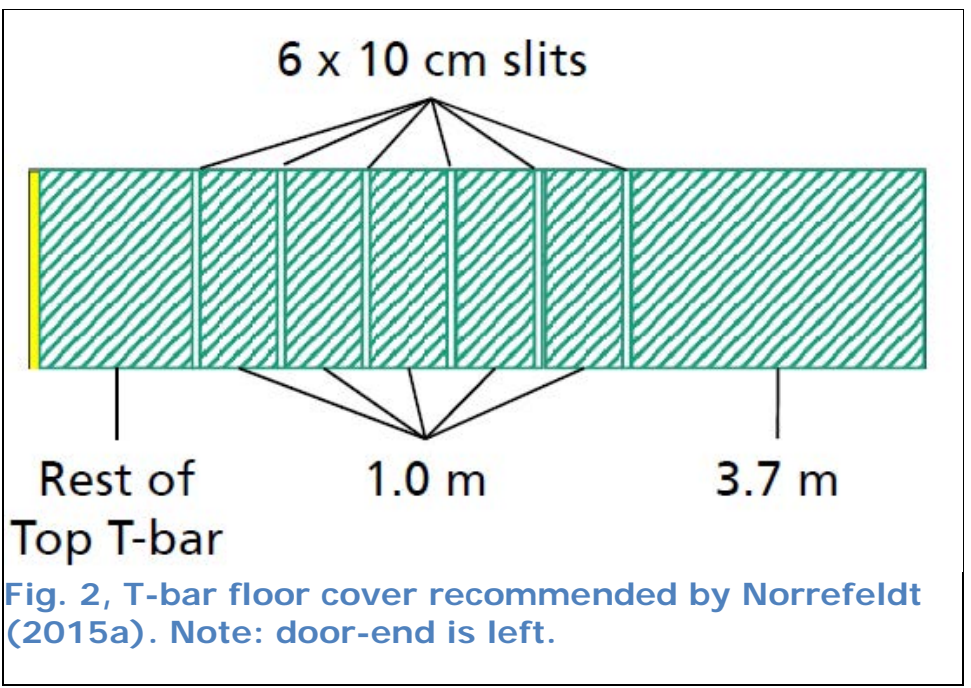
state. Experiments to assess the effect of T-bar floor covers are laborious. Running some extra tests to assess the effect of reefer unit controller settings takes a minimal extra effort. Therefore the opportunity is utilized to also run some tests to assess the cargo temperature effect of controller settings affecting evaporator fan speed and humidity control. 


\subsection{Aim}

The aims of this study are to:

1. Design an optimised T-bar floor cover and assess its effect on cargo temperature distribution.

2. Assess the cargo temperature distribution in a reefer container for a series of controller settings affecting evaporator fan speed and dehumidification operation. 


\section{Theory}

\subsection{Air flow distribution in reefer containers}

For climate control in contained spaces conditioned air needs to be guided to the place where it is needed. This is typically done by air ducts. For example virtually every office building has these air ducts, usually hidden behind the ceilings. In the design of air ducts the diameter of the ducts is tuned to air flow rates: wide ducts close to the air conditioning unit, and small ducts delivering the air to the most distant office space. The relatively high air flow resistance of the air duct outlets, as compared to the resistance inside the ducts, helps to achieve a relatively even air distribution throughout the office building.

T-bars are the air ducts of reefer containers, but there design is rudimentary: the cross section is the same over the complete length, and the air flow resistance of the air outlet at the top of the T-bars is very low. Hence most air escapes from the ducts before reaching the container doorend if no further measures are taken. Therefore dedicated T-bar covers or cargo stowage patterns, closing off the right areas of the T-bar top openings, are a means to guide air to where it is needed and thus improve temperature management. That's why the use of fillers, a.k.a.

dunnage is recommended (see e.g. anonymous, no year; de Haan, no year; Montsma et al., 2011). Also covering parts of the floor has been reported (Cronje et al., 2015; Defraeye et al., 2016; Norrefeldt, 2015b; Elíasson et al., 2013). Lawton (1994; 1999) presents a L-shaped board placed against / on top of the door-end pallets with the aim to exploit the fact that air inside T-bars warms more than in centre T-bars. The test results reported in Lawton (1999) concern a handstowed cargo, while there is no mentioning of palletized cargo. The system is especially meant for tight stows. For loads of trays, specifically facilitating horizontal air flow, even more complex air guidance systems have been proposed (Dodd \& Worthington-Smith, 2006).

Despite all efforts done by others there still is no commonly used simple one-piece T-bar floor cover to improve temperature-distribution in reefer containers independent of cargo stowage. That's a gap filled by this study.

\subsection{Key Performance Indicators}

In an experimental study on temperature distribution in reefer containers lots of data need to be evaluated. The three typical stages of interest are: steady state data, power off data, and recovery data. In an experiment a natural procedure is to first establish steady state (stage 1), then introduce a power off period of a predefined duration (stage 2), and then recover the temperatures (stage 3) to steady state again (stage 1). Fig. 3 shows an arbitrary example. The 'temperature recovery' stage has similarities with the initial pulldown stage after hot-stuffing. The difference is that at the start of a recovery period there are typical temperature gradients in the cargo from warm side temperatures to a colder core, while at the start of an initial pulldown stage all cargo temperatures are approximately equal. 


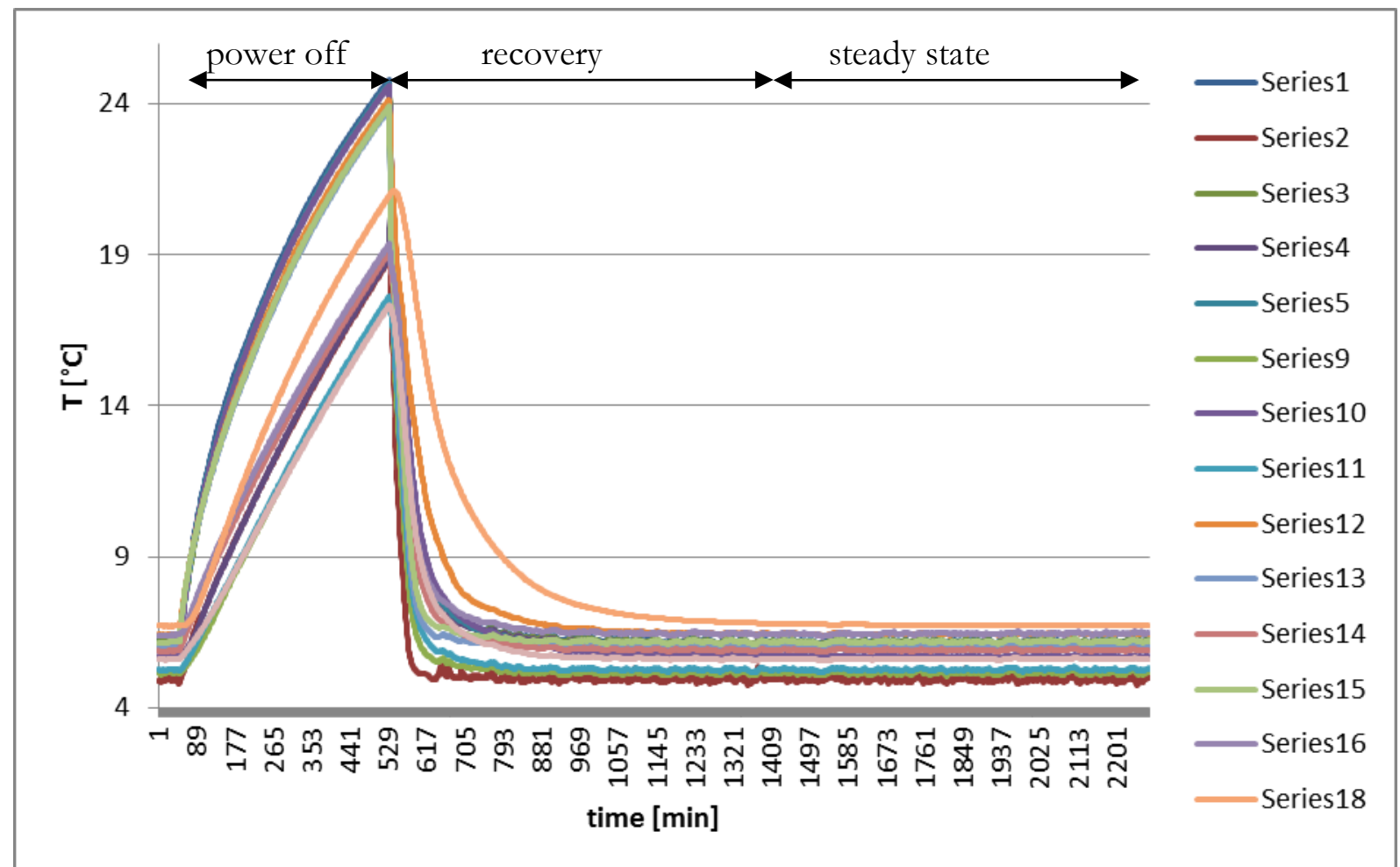

Fig. 3, example of temperatures recorded during the three different test stages.

To condense the information contained in the temperature readings to one, or a few, informative numbers this report uses the key performance indicators listed in Table 1.

Table 1, key performance indicators used for the tests

\begin{tabular}{|l|l|}
\hline $\begin{array}{l}\text { test } \\
\text { condition }\end{array}$ & key performance indicator (KPI) \\
\hline steady state & $\begin{array}{l}\text { Warmest time-averaged sensor minus coldest time-averaged sensor. Time-averages } \\
\text { are taken over a period of not less than } 12 \text { hours, where for none of the } \\
\text { temperature sensors the difference between the first and the last reading is more } \\
\text { than } 0.2^{\circ} \mathrm{C} .\end{array}$ \\
\hline power off & $\begin{array}{l}\text { For each of the temperature sensors assess the temperature deviation from its } \\
\text { steady state after } 8 \text { hours power off. The KPI is then the largest of those N } \\
\text { observed deviation. }\end{array}$ \\
\hline recovery & $\begin{array}{l}\text { Calculate the SECT for each of the temperature sensors. The KPI is then the } \\
\text { largest of those N SECTs. }\end{array}$ \\
\hline
\end{tabular}

The SECT mentioned in Table 1 is the Seven Eighths Cooling Time. The SECT of a specific sensor is defined as the time needed for that sensor to reduce the temperature difference between $\mathrm{T}(0)$ and its steady state temperature $\mathrm{T}_{\mathrm{SS}}$ by seven eighths. In mathematical terms:

$$
S E C T=\underset{t}{\operatorname{argmin}}\left(\frac{T(0)-T(t)}{T(0)-T_{S S}}>\frac{7}{8}\right) \quad \text { [min] }
$$


SECT is a measure used more often to classify precooling operations (see e.g. Brosnan \& Sun, 2001; Defraeye, 2016; Jamal et al., 2015). Note that usually SECT does not use $\mathrm{T}_{\mathrm{ss}}$ but set point temperature $\mathrm{T}_{\text {set }}$. SECT is then seven eighths of the time needed to reach set temperature $\mathrm{T}_{\text {set }}$. In this study that might result in SECT $=\infty$ (infinite) for some sensors because $\mathrm{T}(0)$ is relatively close to $T_{s s}$, and $T_{s s}$ differs quite a lot from $T_{\text {set }}$ for some sensors. Therefore it is chosen to use $T_{s s}$ instead of $\mathrm{T}_{\text {set }}$. 


\section{Equipment specifications}

\begin{tabular}{|l|l|l|}
\hline & manufacturer & Type name \\
\hline Insulated body & MCI Qingdao & MQRS-40HS-062A \\
\hline Cooling / heating unit & Starcool & SCI-40-W \\
\hline
\end{tabular}

\begin{tabular}{|l|l|}
\hline Owner's container identification number & MNBU348354-4 \\
\hline
\end{tabular}

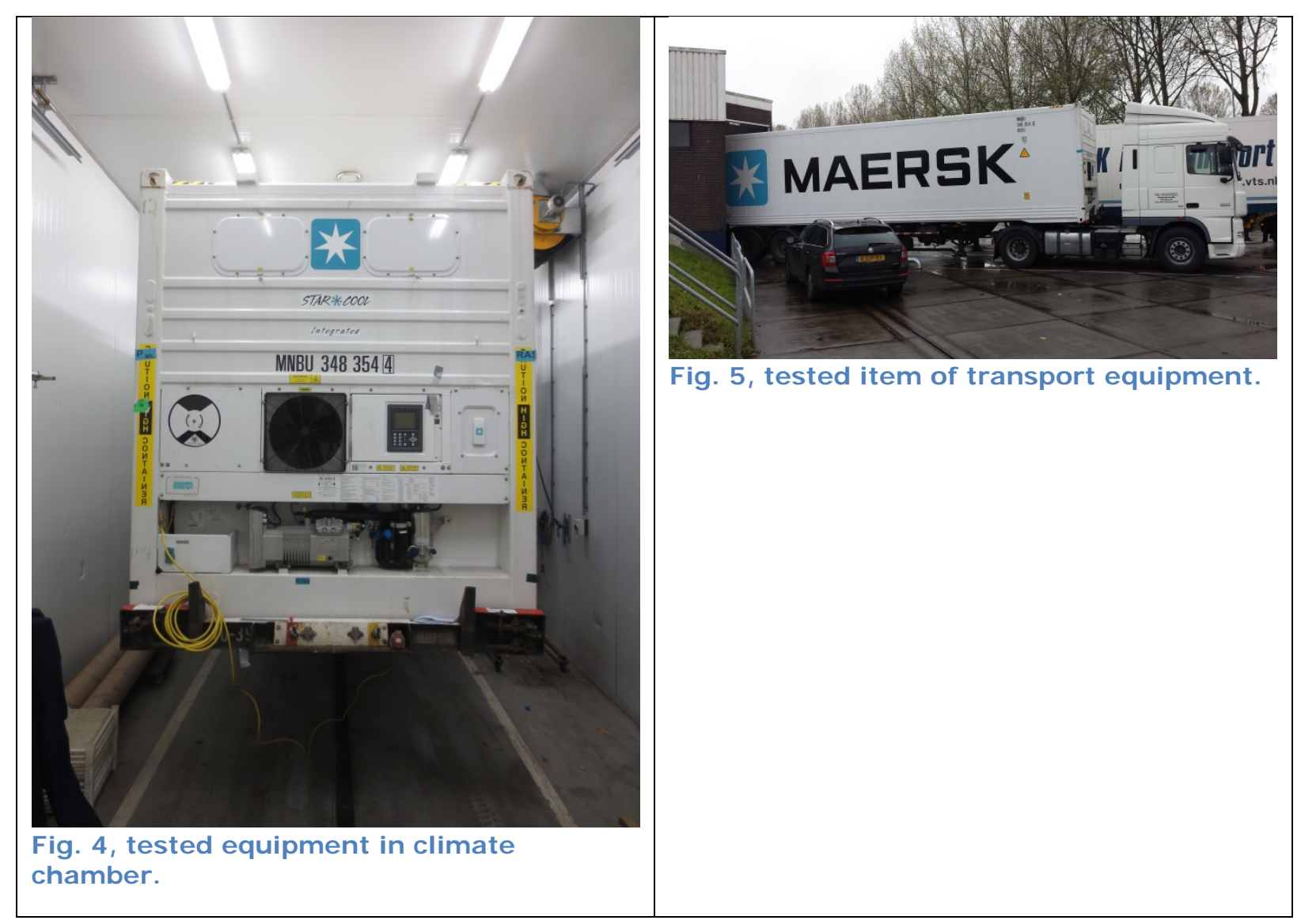

\subsection{Insulated body}

\begin{tabular}{|l|l|}
\hline Description & Value \\
\hline $\begin{array}{l}\text { Container box identification } \\
\text { number }\end{array}$ & QM15-13018 \\
\hline $\begin{array}{l}\text { Date of construction insulated } \\
\text { body }\end{array}$ & $04 / 2015$ \\
\hline External dimension & LxWxH $=1218 \times 244 \times 289 \mathrm{~cm}(40 \mathrm{ft} \mathrm{HC})$ \\
\hline Inside dimensions & LxWxH $=1159 \times 229 \times 255 \mathrm{~cm}$ \\
\hline $\begin{array}{l}\text { Space between end of T-bar and } \\
\text { doors }\end{array}$ & $11.5 \mathrm{~cm}$ \\
\hline return air grid & L x H $=187 \times 24.5 \mathrm{~cm}$ \\
\hline T-bar & height x pitch x opening $=60 \times 63 \times 34 \mathrm{~mm}$ \\
\hline
\end{tabular}




\begin{tabular}{|l|l|}
\hline Description & Value \\
\hline T-bar length & $1135 \mathrm{~cm}$ \\
\hline $\begin{array}{l}\text { Opening between outer-most T- } \\
\text { bars and side walls }\end{array}$ & $45 \mathrm{~mm}$ \\
\hline
\end{tabular}

\subsection{Refrigeration unit type and settings}

\begin{tabular}{|l|l|}
\hline Description & Value \\
\hline Manufacturer & Starcool \\
\hline type & SCI-40-W \\
\hline Serial no. & MNBU3483544 \\
\hline Manufacturing date & $06 / 2015$ \\
\hline Unit's method of drive & Electric, $50 \mathrm{~Hz} / 400 \mathrm{~V}$ \\
\hline Controller's software version & $353 \mathrm{r} 2$ \\
\hline Set defrost interval & AUTO \\
\hline Date of last PTI & 9 Oct. 2015 \\
\hline
\end{tabular}

\subsection{Dummy load during testing}

\begin{tabular}{|l|l|}
\hline Description & Value \\
\hline Dimensions of pallets & $\mathrm{L} \times \mathrm{W} \times \mathrm{H}=120 \times 100 \times 14 \mathrm{~cm}$ \\
\hline Open space for air circulation under pallet & $\begin{array}{l}10 \mathrm{~cm}(9 \mathrm{~cm} \text { in } 1 \text { direction, } 10.8 \mathrm{~cm} \text { in other } \\
\text { direction })\end{array}$ \\
\hline Size of cartons & $\mathrm{L} \times \mathrm{W} \times \mathrm{H}=56.5 \times 38.0 \times 27.5 \mathrm{~cm}$ \\
\hline No. of cartons per layer & 5 \\
\hline No. of carton layers & 7 \\
\hline Height of 2 stacked pallets with 7 tiers of cartons & $224 \mathrm{~cm}$ \\
\hline Distance between last pallets and door & $72 \mathrm{~cm}$ \\
\hline Height of head space & $30 \mathrm{~cm}$ \\
\hline Weight of 2 pallets with 7 tiers of empty cartons & $52 \mathrm{~kg}$ \\
\hline Total payload mass & $\begin{array}{l}580 \mathrm{~kg} \text { wooden pallets, and } 460 \mathrm{~kg} \text { cardboard } \\
\text { cartons. }\end{array}$ \\
\hline Specific heat & $\begin{array}{l}\text { Wood: } 0.48 \mathrm{cal} . / \mathrm{g} .{ }^{\circ} \mathrm{C} \text {, paperboard: } 0.33 \\
\text { cal. } / \mathrm{g} .{ }^{\circ} \mathrm{C}\end{array}$ \\
\hline Thermal mass & $430.2 \mathrm{Kcal} /{ }^{\circ} \mathrm{C}$ \\
\hline
\end{tabular}


Cartons were stacked on pallets. Two pallets with cartons were put on top of each other and then shrink wrapped. Shrink wrapping was done such that most of the $10 \mathrm{~cm}$ pallet space underneath the lowest cartons was kept open for horizontal air flow. Pallets were stowed in the container in a block pattern (Fig. 9). Pallets were stuffed in the container without covering the openings between the side walls and the two outer-most T-bars. Because the stacking of cartons on the pallets was pretty straight and cartons do not bulge virtually none of the cargo touches the side

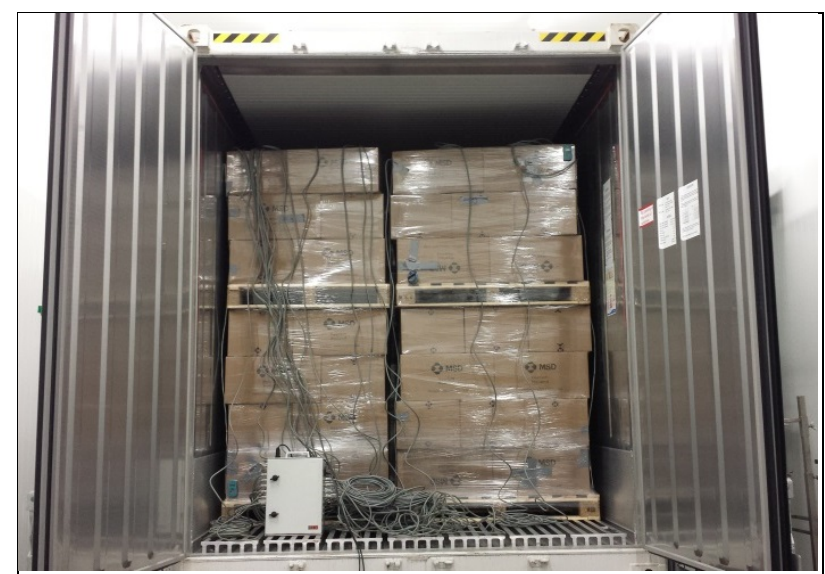

Fig. 6, view of the dummy load as stowed in the container. walls.

\subsection{Logger types and positions}

During the tests four types of temperature sensors were used (Table 2).

Table 2, used logger types.

\begin{tabular}{|l|l|l|l|}
\hline Logger type & number & measured parameter & owner \\
\hline $\begin{array}{l}\text { 3-wire PT100 sensors } \\
\text { (so-called ATP sensors) }\end{array}$ & 20 inside, 12 outside & T & Wageningen UR \\
\hline LogTags (Fig. 7) & 18 & T & Wageningen UR \\
\hline Escorts (Fig. 8) & 3 & T, RH & Wageningen UR \\
\hline $\begin{array}{l}\text { Multi-alarm TempTale4 } \\
\text { with USB connector }\end{array}$ & 6 & T & MSD \\
\hline
\end{tabular}

The 12 outside ATP sensors are all placed at $10 \mathrm{~cm}$ from the container wall. Eight are positioned at the eight corners. The other four are positioned at the centre faces of the four largest container sides. See Fig. 10.

Placement of the 20 inside ATP sensors is described with reference to Fig. 9. Eight sensors, no. 1 till 4 and 13 till 16, are taped to the side of cartons all the way down (D) or up (U) at the eight corners of the cargo stow, composed of 20 pallets. ATP sensors 6,7 and 8 are positioned at Tbar entry; 19 at return air grid centre; 17 in the T-bar. The stow has five chimneys. In each chimney one sensor is taped to the side of a carton (no. 5, 9, 10, 11), in the door-end chimney two sensors are placed (no. 12, 20). The last ATP sensor, no. 18, is placed in pallet 17 at the $6^{\text {th }}$ layer from the bottom in the centre box at the door-end. This is known to be the area with slowest response to temperature set point changes. Sensor 18 is especially used to check if all temperatures are in steady state. Taping of sensors to the sides of cartons is done in this respect that the sensor tips stay approximately $1 \mathrm{~cm}$ away from cartons and do not touch the container wall (Fig. 11). The positions of all other loggers are described in Table 3 - Table 6. 

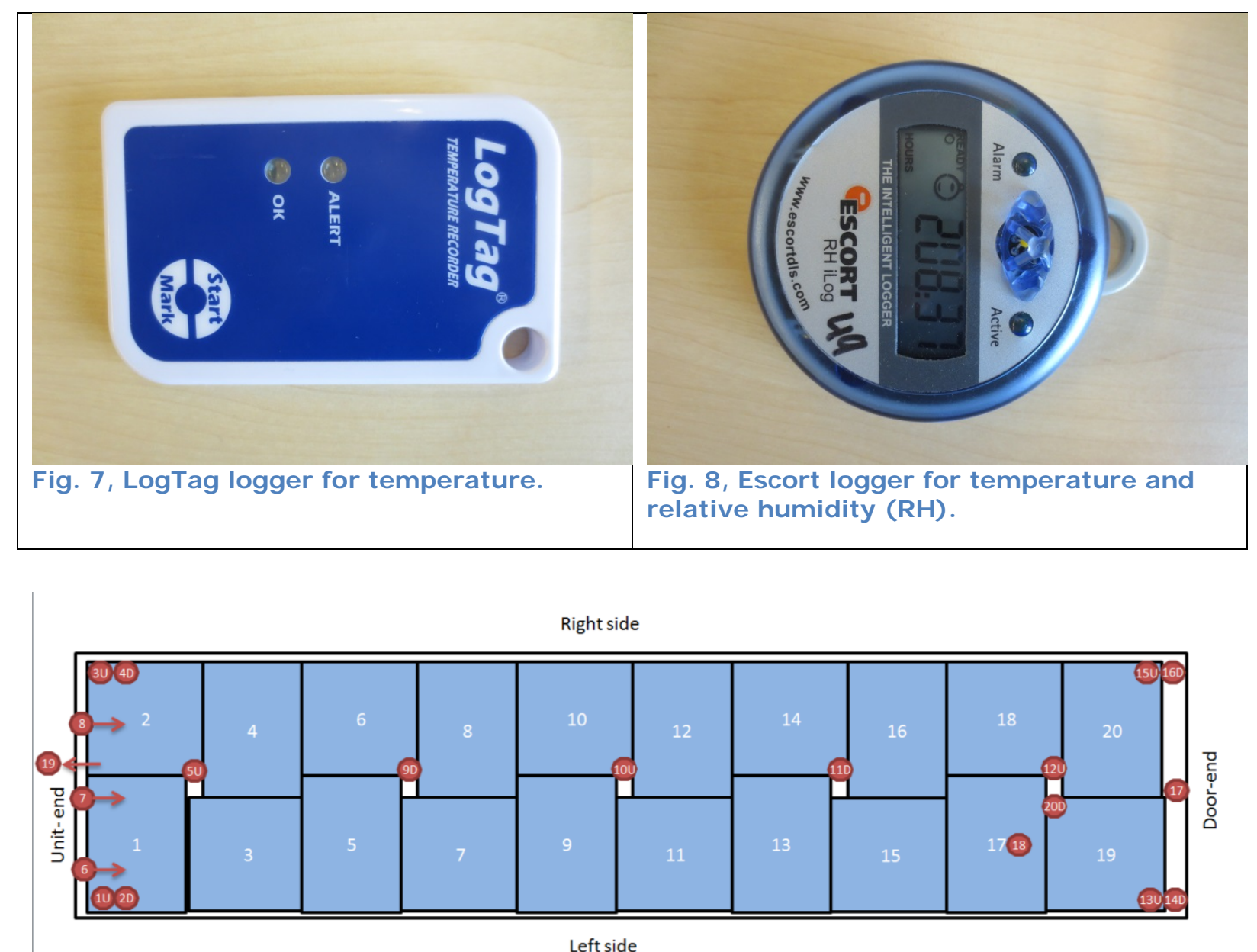

Fig. 9, top view of pallet positions, pallet numbering and numbering of internal ATP sensors.

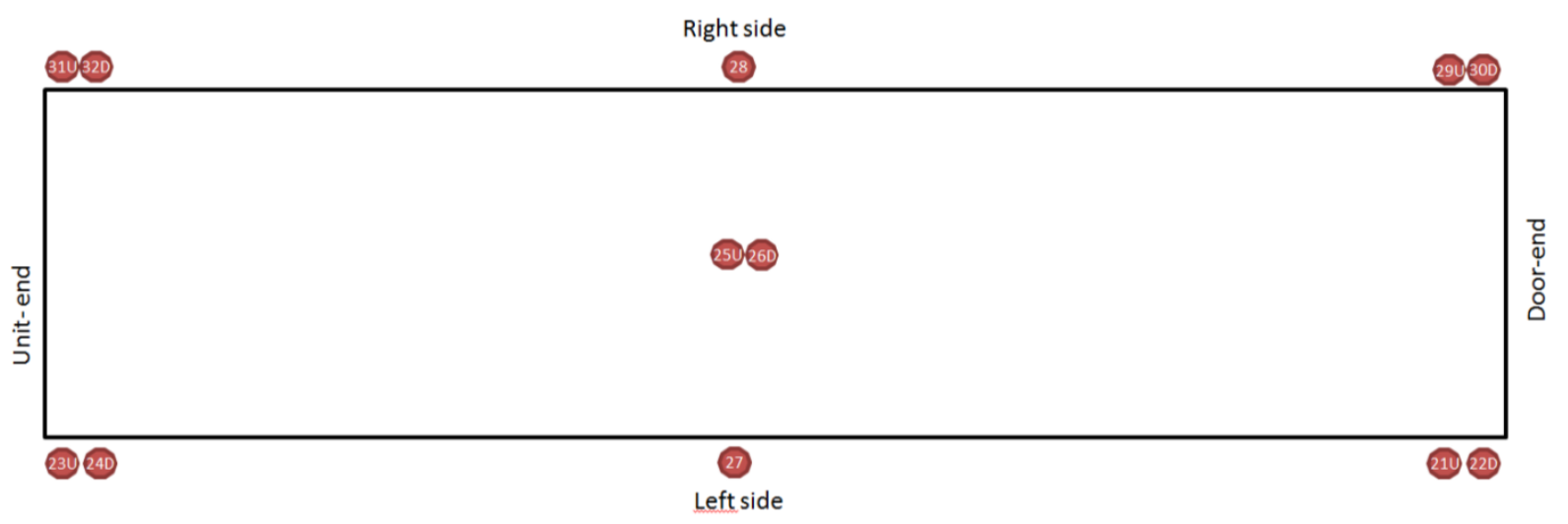

Fig. 10, top view with numbering of external ATP sensors.

Table 3, position of internal ATP sensors.

\begin{tabular}{|c|c|c|c|c|}
\hline sensor & pallet & Up/Down & Left/Right & Front/Back \\
\hline 1 & 1 & $\mathrm{U}$ & $\mathrm{L}$ & $\mathrm{F}$ \\
\hline 2 & 1 & $\mathrm{D}$ & $\mathrm{L}$ & $\mathrm{F}$ \\
\hline 3 & 2 & $\mathrm{U}$ & $\mathrm{R}$ & $\mathrm{F}$ \\
\hline 4 & 2 & $\mathrm{D}$ & $\mathrm{R}$ & $\mathrm{F}$ \\
\hline 5 & 2 & $\mathrm{U}$ & $\mathrm{L}$ & $\mathrm{B}$ \\
\hline
\end{tabular}




\begin{tabular}{|c|c|c|c|c|}
\hline 6 & \multicolumn{5}{|c|}{ in unit-end entrance of 6th T bar from left (controller side) } \\
\hline 7 & \multicolumn{4}{|c|}{ in unit-end entrance centre T-Bar } \\
\hline 8 & in unit-end entrance of 6th T-bar from right (Fresh Air Exchange side) \\
\hline 9 & 6 & $\mathrm{D}$ & $\mathrm{L}$ & $\mathrm{B}$ \\
\hline 10 & 10 & $\mathrm{U}$ & $\mathrm{L}$ & $\mathrm{B}$ \\
\hline 11 & 14 & $\mathrm{D}$ & $\mathrm{L}$ & $\mathrm{B}$ \\
\hline 12 & 18 & $\mathrm{U}$ & $\mathrm{L}$ & $\mathrm{B}$ \\
\hline 13 & 19 & $\mathrm{U}$ & $\mathrm{L}$ & $\mathrm{B}$ \\
\hline 14 & 19 & $\mathrm{D}$ & $\mathrm{L}$ & $\mathrm{B}$ \\
\hline 15 & 20 & $\mathrm{U}$ & $\mathrm{R}$ & $\mathrm{B}$ \\
\hline 16 & 20 & $\mathrm{D}$ & $\mathrm{R}$ & $\mathrm{B}$ \\
\hline 17 & \multicolumn{6}{|l|}{ in centre T-bar against pallet 20 at door-end } \\
\hline 18 & 17 & $6^{\text {th }}$ layer from bottom in the centre box at the door-end \\
\hline 19 & \multicolumn{5}{|c|}{} \\
\hline 20 & centre of return air grid & L & B \\
\hline
\end{tabular}

Table 4, position of Escort loggers for T and RH.

\begin{tabular}{|l|l|}
\hline serial no. & position \\
\hline $1203-0201$ & centre of return air grid \\
\hline $1204-0022$ & on top of pallet above container's centre \\
\hline $1204-0049$ & against pallet 20 @ carton layer 5, between pallet and door, at container's central axis. \\
\hline
\end{tabular}

Table 5, position of LogTag loggers (always placed in pairs of two)

\begin{tabular}{|c|c|}
\hline LogTags & in carton next to ATP no. \\
\hline $337699 \& 337680$ & 1 \\
\hline $337732 \& 337712$ & 2 \\
\hline $337682 \& 337715$ & 3 \\
\hline $337664 \& 334237$ & 4 \\
\hline $337686 \& 337723$ & 13 \\
\hline $337657 \& 337707$ & 14 \\
\hline $337690 \& 337691$ & 15 \\
\hline $337674 \& 337660$ & 16 \\
\hline $337704 \& 337658$ & 18 \\
\hline
\end{tabular}

Table 6, position of TempTale 4 recorders

\begin{tabular}{|c|l|}
\hline serial no. & \multicolumn{1}{|c|}{ position } \\
\hline 2933502321 & in carton next to ATP 1 \\
\hline 2933502360 & in carton next to ATP 4 \\
\hline 2933502378 & in carton next to ATP 14 \\
\hline 2933502361 & in carton next to ATP 15 \\
\hline 2933502394 & outside at reefer unit \\
\hline 2933502399 & outside at door \\
\hline
\end{tabular}


Although multiple types of loggers are installed, analysis is solely based on temperatures recorded by the ATP loggers (Table 3, Fig. 9).

\subsection{T-bar cover}

Table 7, tested T-bar covers.

\begin{tabular}{|l|l|}
\hline cover no. & Description \\
\hline cover 1 & see Fig. 12, Fig. 13 and accompanying text \\
\hline cover 2 & $\begin{array}{l}=\text { cover } 1 \text { minus the } 58 \text { cm length covering the door-end T-bar area free of cargo. } \\
\text { See Fig. } 14 \text { and Fig. } 13 .\end{array}$ \\
\hline cover 3 & See Fig. 15 \\
\hline cover 4 & $=$ cover 2 with modified holes pattern. See Fig. 16, Fig. 17 and accompanying text. \\
\hline
\end{tabular}

Cover 1, the first T-bar cover version, is sketched in Fig. 12 and Fig. 13. The internal container width is $2280 \mathrm{~mm}$, the gaps between the outermost T-bars and the walls have an opening of $45 \mathrm{~mm}$, while the cover width is only $2175 \mathrm{~mm}$. As a consequence the cover completely covers all openings between T-bars, while leaving the gaps between the outermost T-bars and the walls completely open.

Also note that the T-bar cover is longer than the internal container length. One end of the T-bar cover is placed at the end of the T-bar floor at the door-end. Then it is unrolled. Consequentially $29.5 \mathrm{~cm}$ are left over at the unit-end's T-bar end. This covers the baffle plate. Advantage is that this makes the air flow distribution more robust to poor connections between baffle plate and T-bar entry.

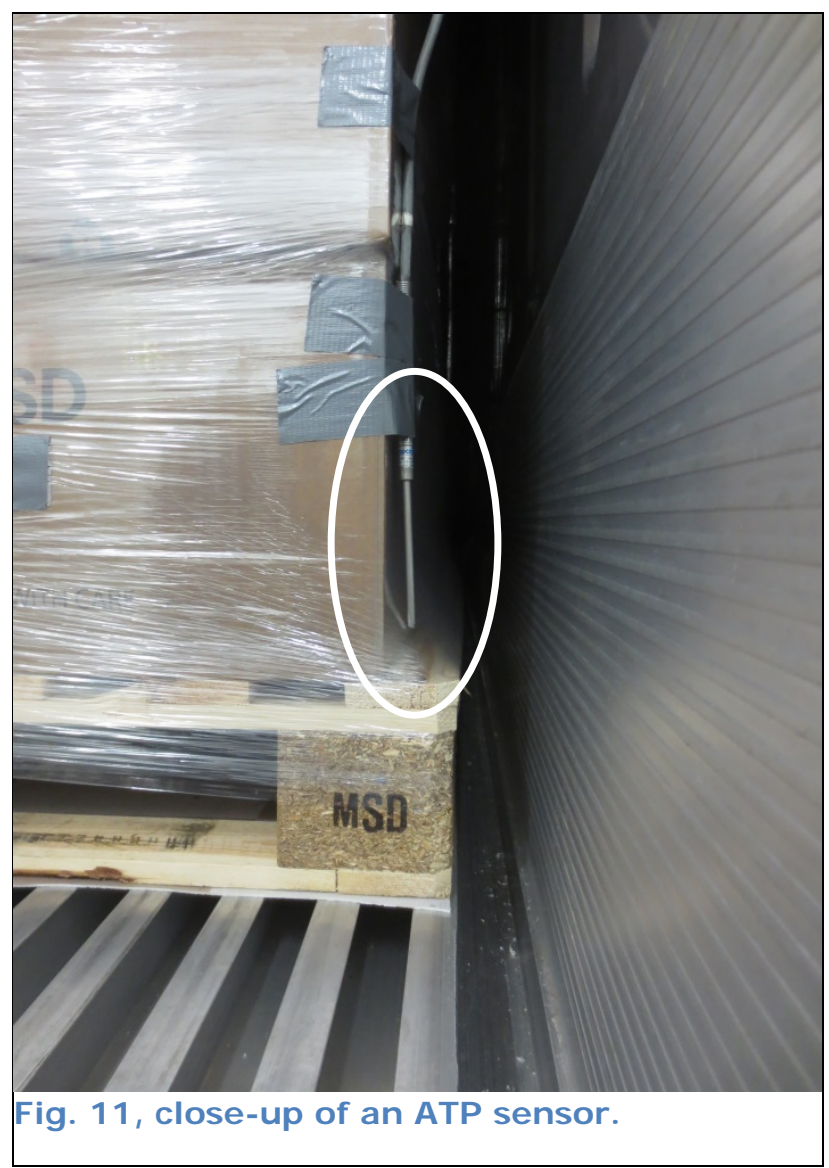




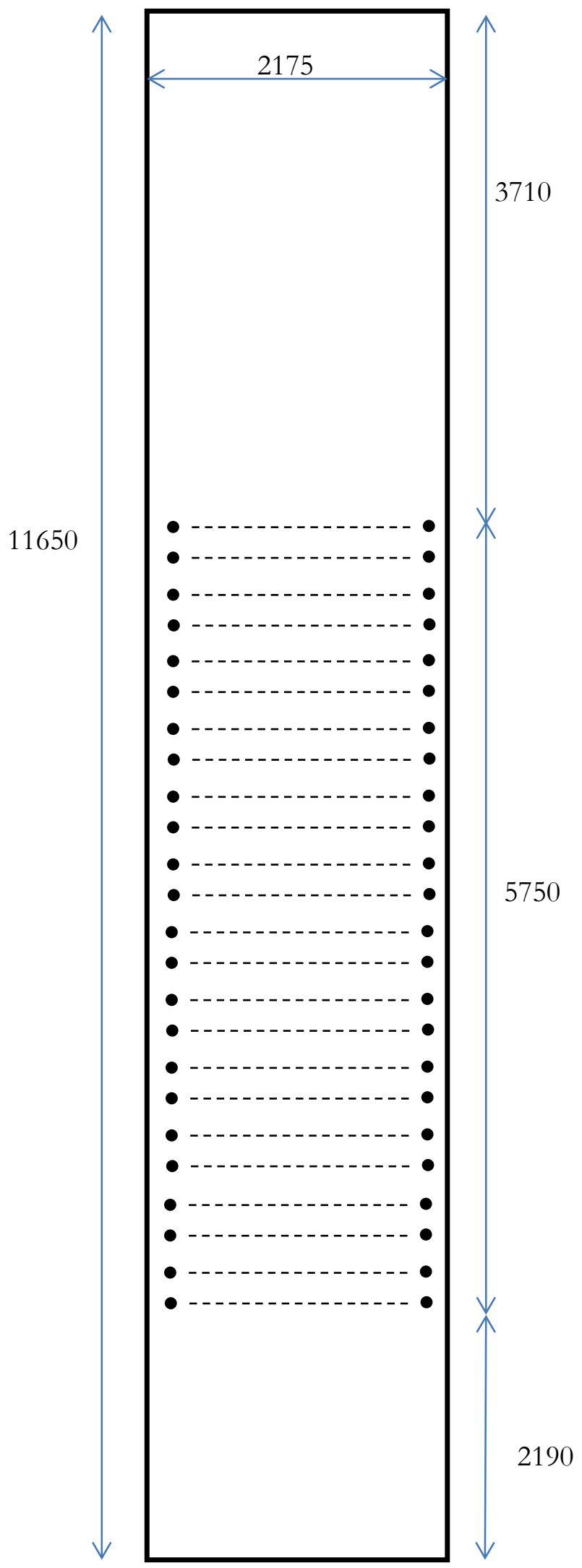

Fig. 12, sketch of floor cover 1 (dimensions in $\mathrm{mm}$, unit-end at top of figure). The dotted lines illustrate the $\mathbf{2 4}$ rows of floor perforations. For more details of the floor perforation pattern see Fig. 13. 


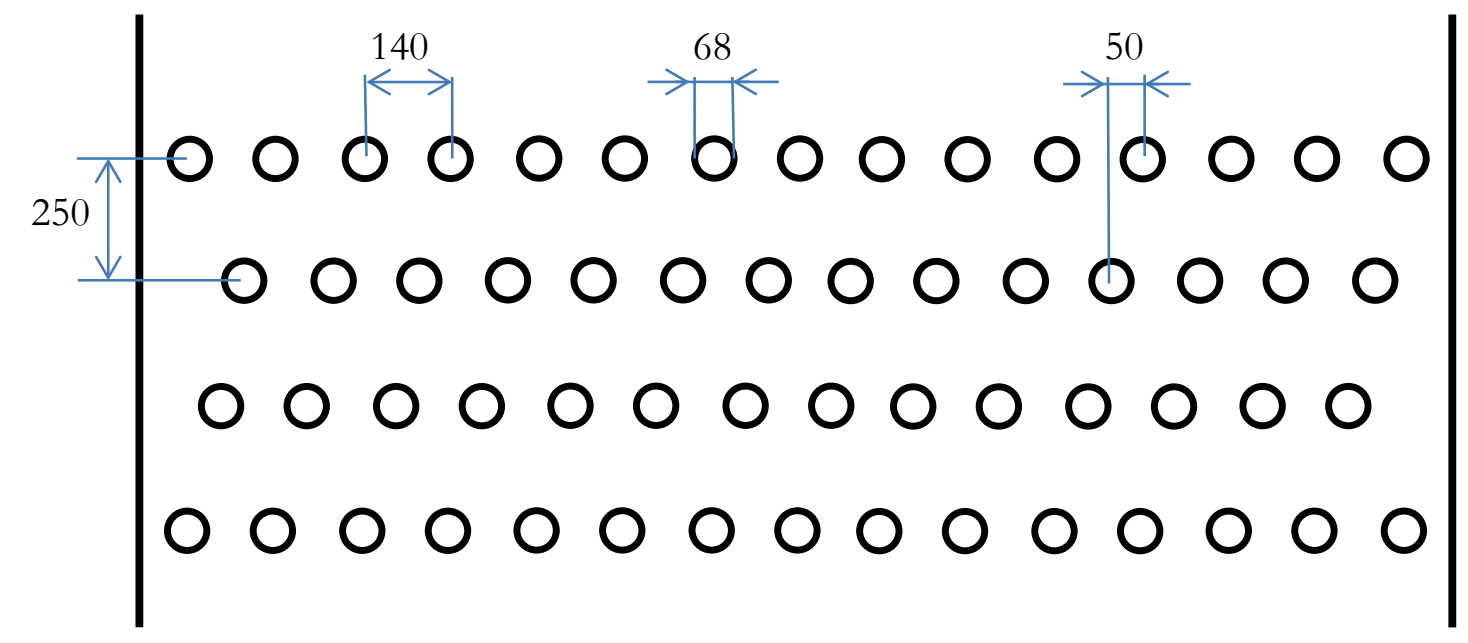

Fig. 13, close-up of a floor cover (version 1 and 2 ) section showing four of the 24 rows of holes (dimensions in $\mathrm{mm}$ ). 


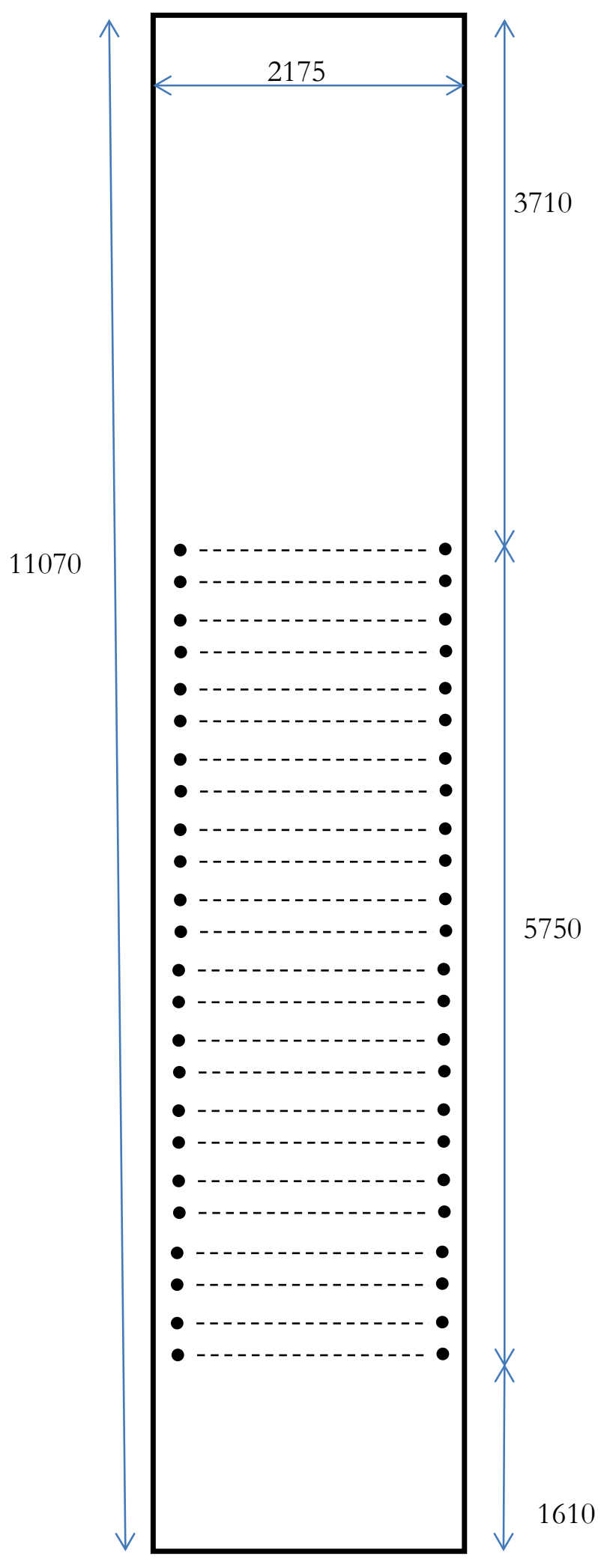

Fig. 14, sketch of floor cover 2 (dimensions in $\mathrm{mm}$ ). The dotted lines illustrate the 24 rows of floor perforations. For more details of the floor perforation pattern see Fig. 13. 


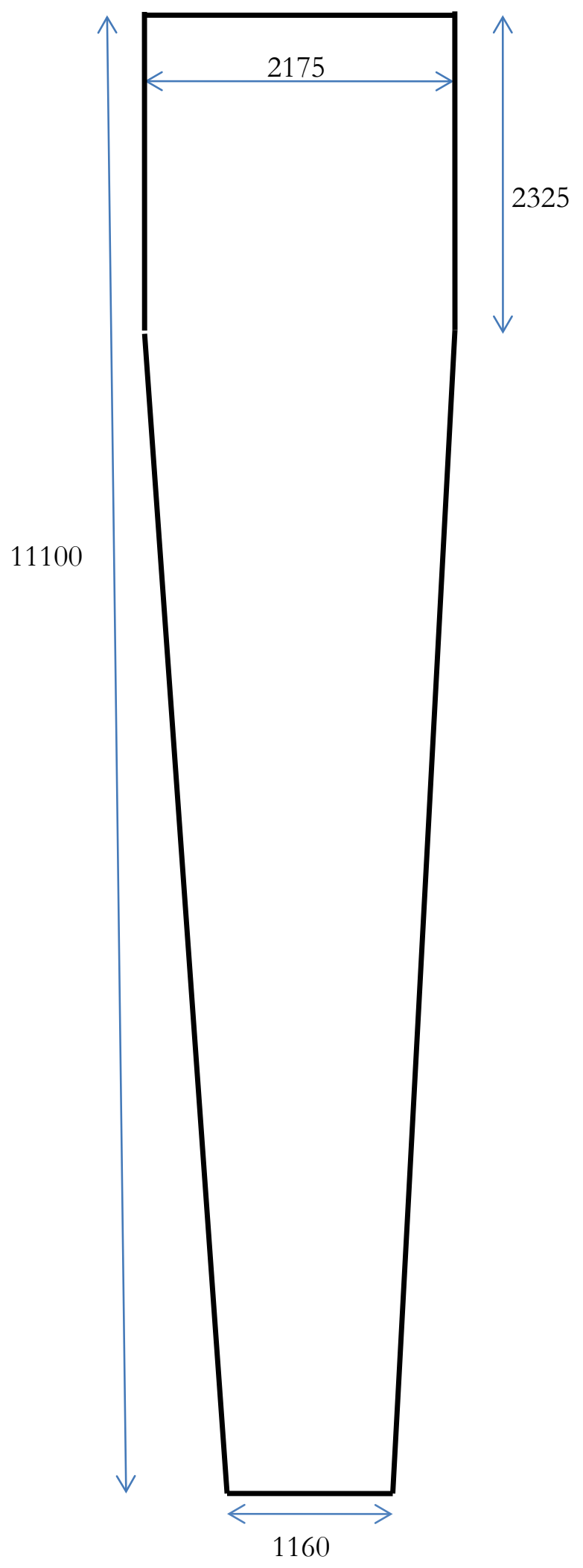

Fig. 15, sketch of floor cover 3 (dimensions in $\mathrm{mm}$ ). The narrow end is placed at doorend $58 \mathrm{~cm}$ from the end of the T-bar. As a result the $2175 \mathrm{~mm}$ wide section at the unitend covers $2000 \mathrm{~mm}$. of T-bar and $325 \mathrm{~mm}$ of baffle plate. 


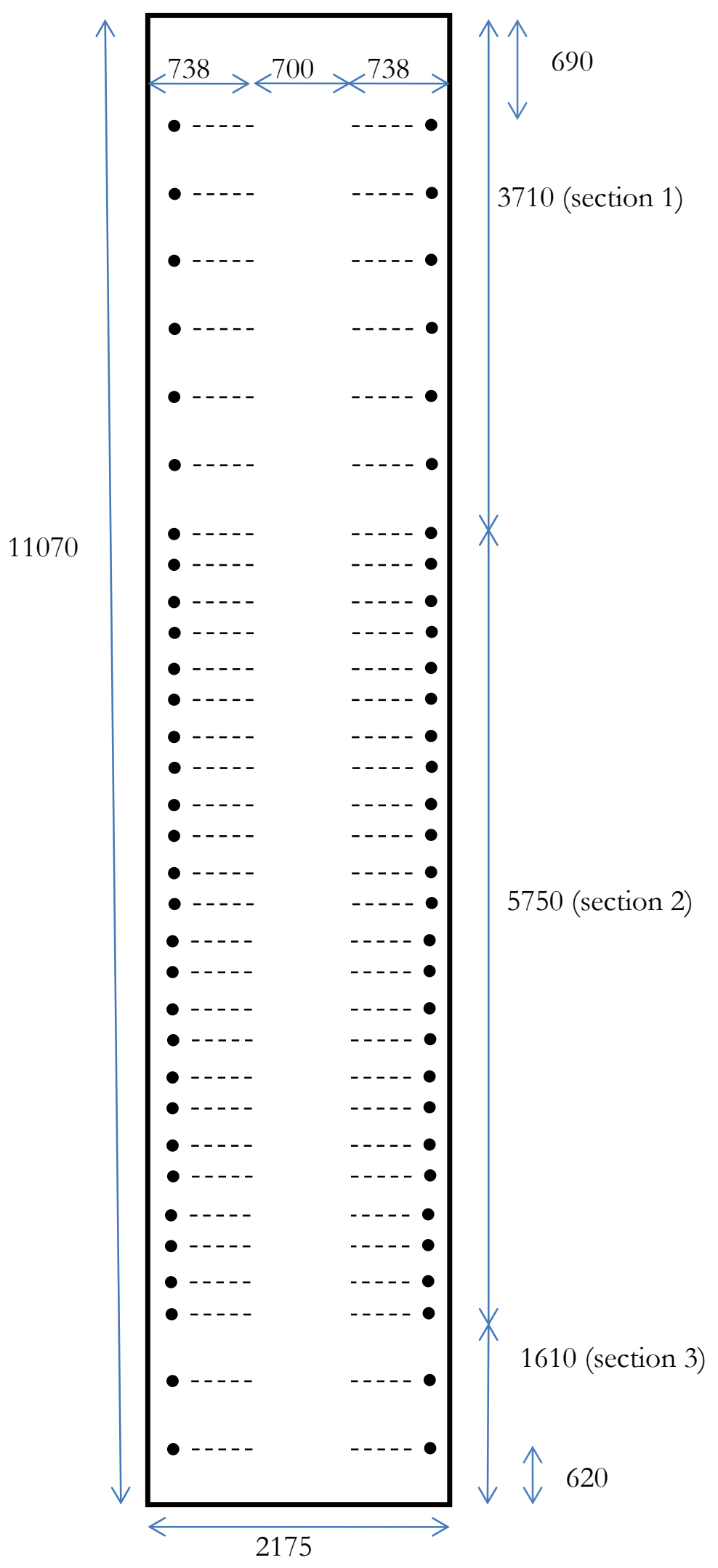

Fig. 16, sketch of floor cover 4 (dimensions in $\mathrm{mm}$ ). The dotted lines illustrate the 32 rows of floor perforations. For more details of the floor perforation pattern see Fig. 17. 
The dimensions of floor cover 4 are identical to those of cover 2 (Fig. 14). The difference is in the pattern of holes. In the middle of cover 4 a band of $70 \mathrm{~cm}$ wide over the full length of the cover is free of holes, thus completely blocking the 10 centre T-bar openings over the full cover length. In section 2 (Fig. 16) the area left and right of this centre band is perforated as in cover 2 (see Fig. 17). In sections 1 and 3 the perforation pattern differs from that in section 2 in only one way: the distance between the rows is 500 instead of $250 \mathrm{~mm}$.

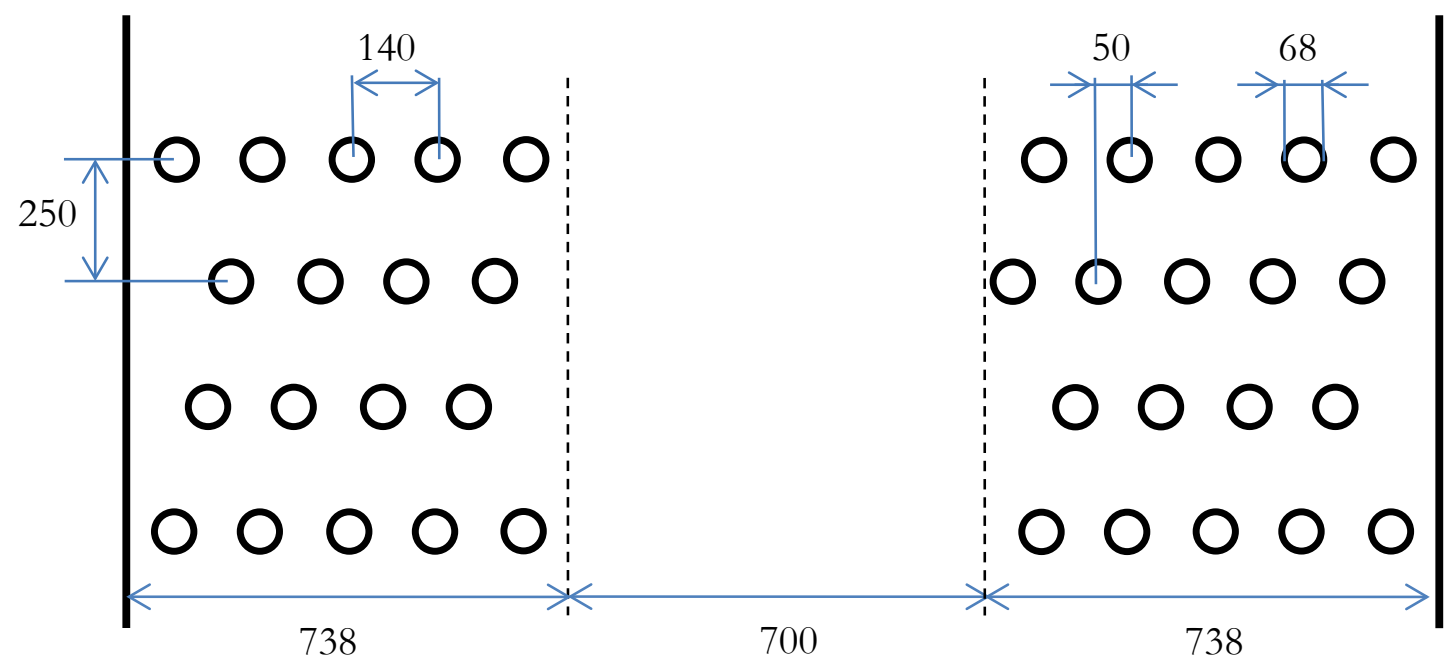

Fig. 17, close-up of floor cover 4 section 2 showing four of the 24 rows of holes (dimensions in $\mathrm{mm}$ ). In sections 1 and 3 the pattern is identical, but rows are $500 \mathrm{~mm}$ apart. 


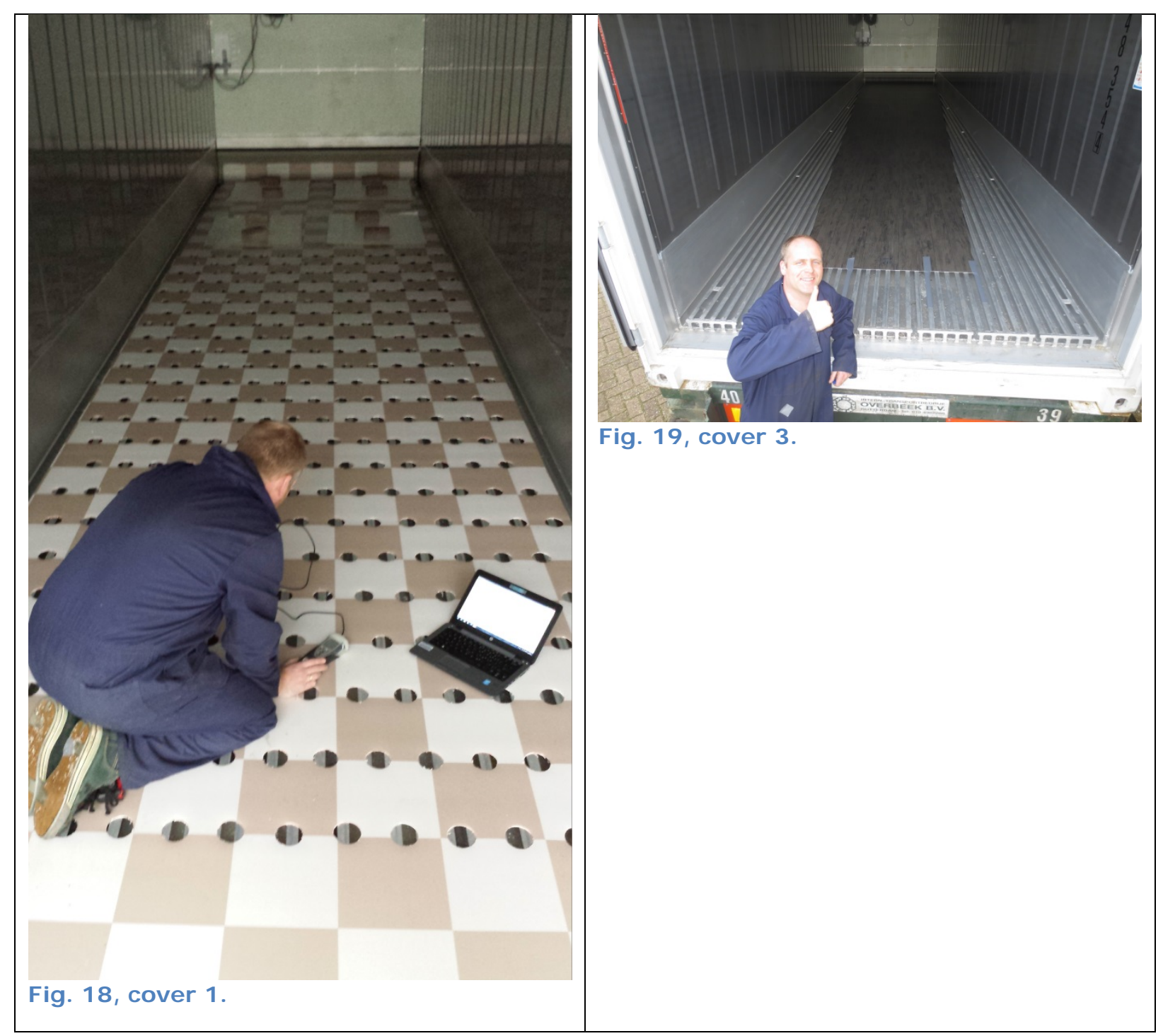




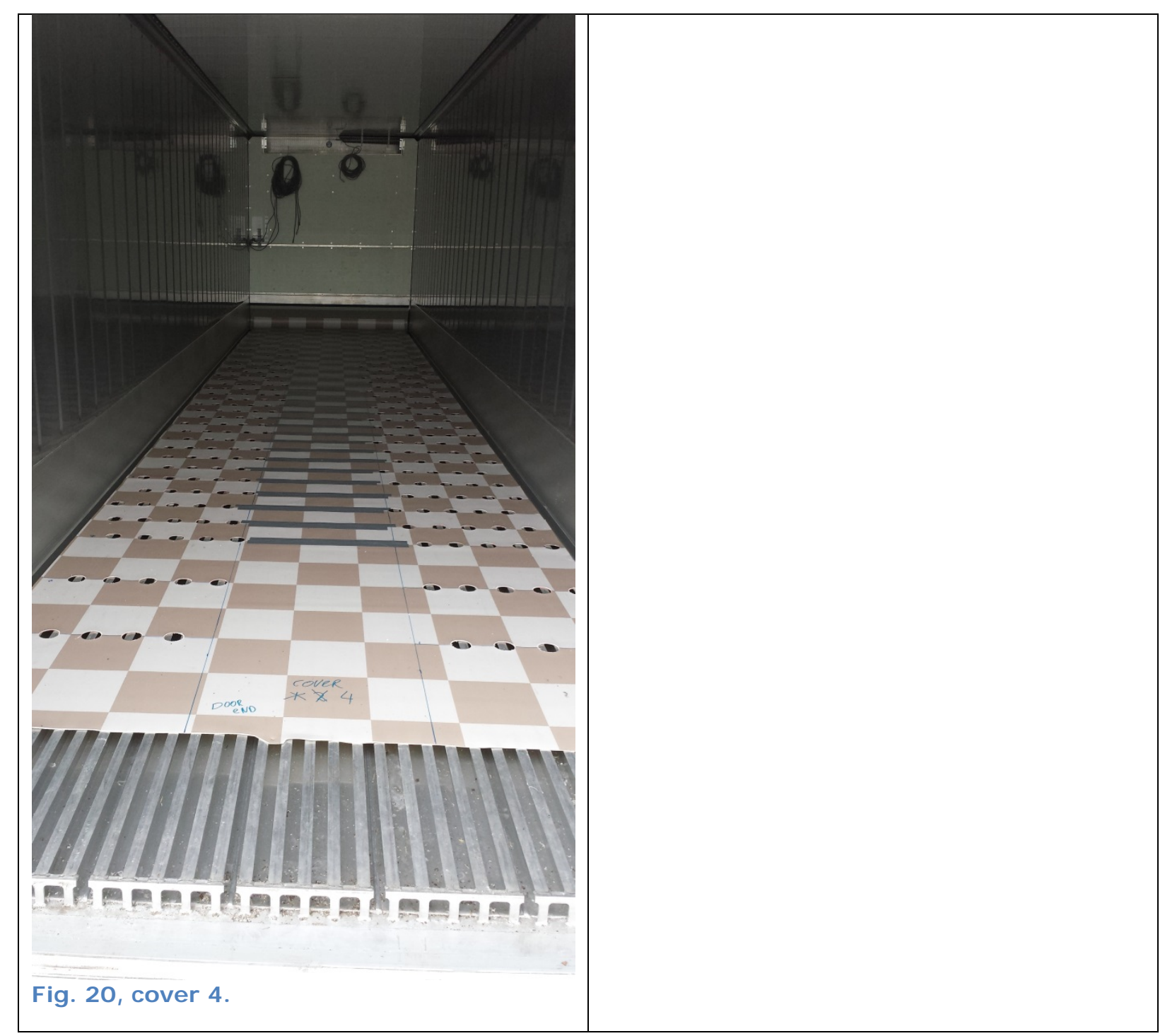




\section{$4 \quad$ Test program}

A $40 \mathrm{ft} \mathrm{HC}$ reefer container was stuffed with 20 double-stacked pallets loaded with empty cartons. Note that a double-stacked pallet consists of two pallets with payload, thus 20 doublestacked pallets occupy 20 pallet positions in a container (Fig. 21, Fig. 22). 20 ATP temperature sensors were positioned throughout the container (Fig. 9), and 12 outside (Fig. 10). In a climate chamber at Wageningen UR temperatures were measured in a series of steady state test conditions interrupted by power loss \& recovery tests. Table 8 lists the test conditions in chronological order. Throughout the tests a steady state is defined as a period of at least 12 hours, where for none of the ATP temperature sensors the difference between the first and the last reading is more than $0.2^{\circ} \mathrm{C}$.

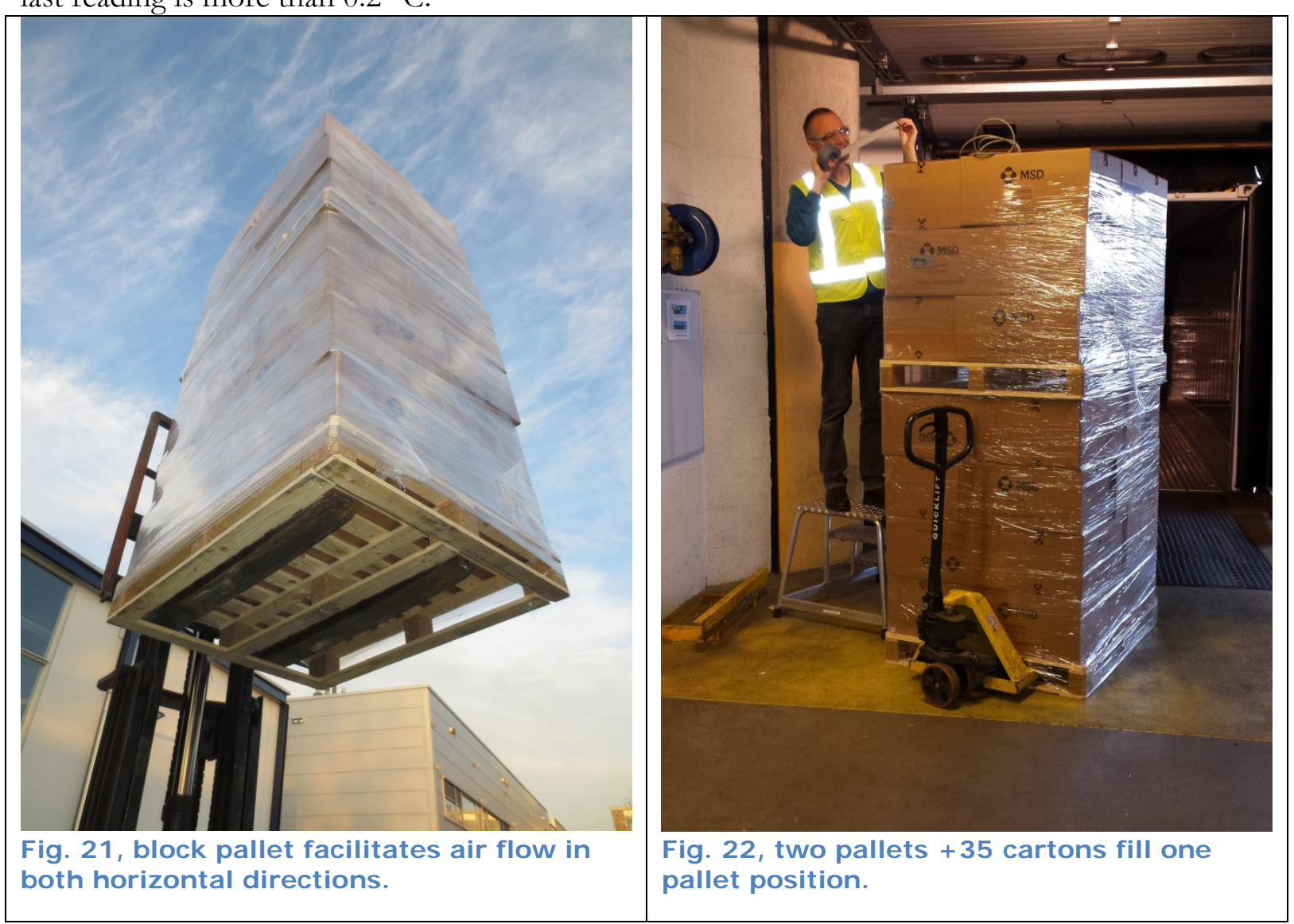


Table 8, test program to assess cargo temperature distribution.

\begin{tabular}{|c|c|c|c|c|c|c|}
\hline Test no. & Tset $\left[{ }^{\circ} \mathrm{C}\right]$ & $\begin{array}{l}\text { Tamb } \\
{\left[{ }^{\circ} \mathrm{C}\right]}\end{array}$ & $\begin{array}{l}\text { Evap fan } \\
\text { speed }\end{array}$ & $\begin{array}{l}\text { RHset } \\
{[\%]}\end{array}$ & $\begin{array}{l}\text { FAE } \\
{\left[\mathrm{m}^{3} / \mathrm{h}\right]}\end{array}$ & $\begin{array}{l}\text { T-bar } \\
\text { cover }\end{array}$ \\
\hline 1. & +5 & +45 & High & OFF & 0 & $\mathrm{No}$ \\
\hline 2. & \multicolumn{2}{|c|}{ Power loss \& recovery } & High & OFF & 0 & No \\
\hline 3. & +5 & +45 & $\begin{array}{l}\text { Low (imposed } \\
\text { by dehum.) }\end{array}$ & $50 \%$ & 50 & No \\
\hline 4. & +5 & +45 & Low & OFF & 50 & No \\
\hline 5. & +5 & +45 & Low & OFF & 0 & $\mathrm{No}$ \\
\hline 6. & \multicolumn{2}{|c|}{ Power loss \& recovery } & Low & OFF & 0 & $\mathrm{No}$ \\
\hline 7. & +30 & 0 & High & OFF & 0 & $\mathrm{No}$ \\
\hline 8. & \multicolumn{2}{|c|}{ Power loss \& recovery } & High & OFF & 0 & No \\
\hline 9. & +30 & 0 & High & $50 \%$ & 0 & $\mathrm{No}$ \\
\hline 10. & +30 & 0 & Low & OFF & 0 & $\mathrm{No}$ \\
\hline 11. & \multicolumn{2}{|c|}{ Power loss \& recovery } & Low & OFF & 0 & $\mathrm{No}$ \\
\hline 12. & +5 & +45 & High & OFF & 0 & cover 1 \\
\hline 13. & +5 & +45 & High & OFF & 0 & cover 2 \\
\hline 14. & \multicolumn{2}{|c|}{ Power loss \& recovery } & High & OFF & 0 & cover 2 \\
\hline 15. & +5 & +45 & Low & $\mathrm{OFF}$ & 0 & cover 2 \\
\hline 16. & +5 & +45 & High & OFF & 0 & cover 3 \\
\hline 17. & \multicolumn{2}{|c|}{ Power loss \& recovery } & High & OFF & 0 & cover 3 \\
\hline 18. & \multicolumn{2}{|c|}{ Power loss \& recovery } & High & OFF & 0 & cover 4 \\
\hline 19. & +5 & +45 & High & OFF & 0 & cover 4 \\
\hline 20. & +5 & +45 & Low & OFF & 0 & cover 4 \\
\hline
\end{tabular}

Note that the test program in Table 8 was not exactly defined a priori, but has been amended to the progression of insight during the tests cyclus. For example Fresh Air Exchange (FAE) was set to $50 \mathrm{~m}^{3} / \mathrm{h}$ during the dehumidification test to make sure there was some moisture load, and hence a need to actively dehumidify, during test 3 . Then the natural question arises: is a difference observed between test 3 and test 5 due to the RH setting or due to FAE? Therefore it was decided to insert test 4 . Also the tests with the floor covers, tests 12 till 20, seem a bit unbalanced. This is due to time limitations. Where time allowed 3 tests were done per floor cover (e.g. test 13 till 15 for cover 2). The steady state tests at high speed evaporator fans are most interesting: tests $12,13,16$, and 19. Due to time limitations some of the two less interesting test conditions were skipped for some covers. One may note that the testing of floor covers in heating mode conditions has been skipped completely: again a matter a time limitations and priorities. 


\section{$5 \quad$ Results}

\subsection{Air flow rates}

For each cover the air velocities in the centre of the T-bars were measured at Tset $=+5{ }^{\circ} \mathrm{C}$ and high speed evaporator fans using a hot wire anemometer. The air flow rate $\mathrm{q}$ in the T-bars at $\mathrm{x}$ meters from the unit-end was subsequently calculated as:

$$
q(x)=\operatorname{avg}(v(x)) *(\text { Tbar height }) * \text { container width } * 3600 \quad\left[\mathrm{~m}^{3} / \mathrm{h}\right]
$$

The resulting air flow rates are presented in Fig. 23.

For comparison note that without T-bar cover at $0 \mathrm{~m}$ from the unit-end and $50 \mathrm{~Hz}$ power supply air flow rate is approx. $4500 \mathrm{~m}^{3} / \mathrm{h}$ (Norrefeldt, 2015a, Montsma et al., 2011). Without T-bar cover this air rapidly escapes from the T-bars and already at $6 \mathrm{~m}$. from the unit-end air flow rates are then typically below $1000 \mathrm{~m}^{3} / \mathrm{h}$ (Montsma et al., 2011).

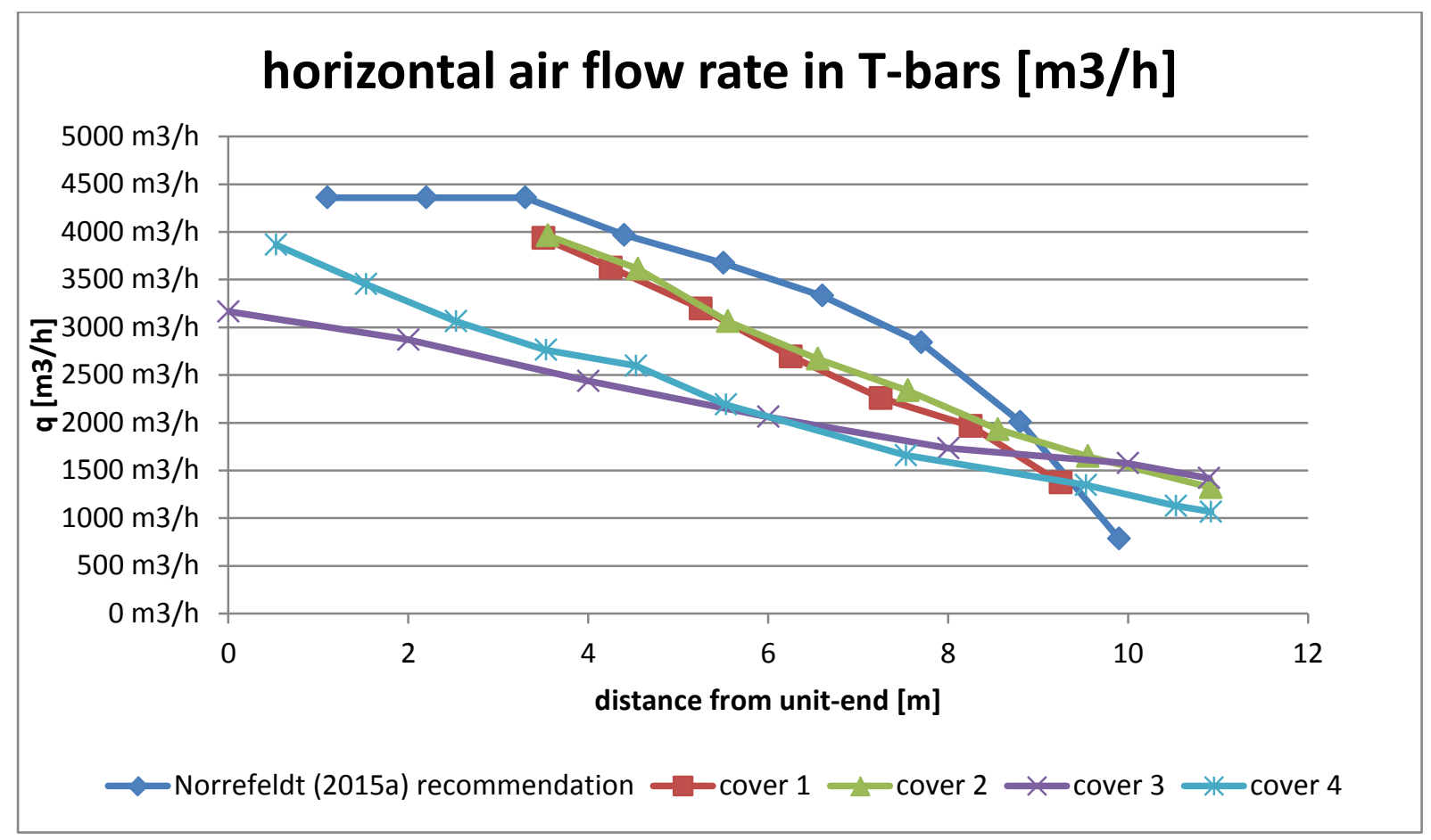

Fig. 23, horizontal air flow rates measured in T-bars.

\subsection{Temperatures}

The analysis of temperatures presented in Table 9 and Table 10 is limited to the internal ATP sensors. The last column in Table 9 is the average of ATP sensors $6 \sim 8$ minus ATP sensor 19 . All other analyses in Table 9 and Table 10 are based on the transport volume ATP sensors. Definition of transport volume ATP sensors: transport volume ATP sensors are sensors $1 \sim 5,9$ $\sim 16,18$, and 20 . These are the sensors positioned directly in and around the cargo, whereas sensors $6 \sim 8$ and 17 are positioned in the T-bar, and sensor 19 is positioned in the return air grid (Table 3). 
Table 9 presents the steady state temperatures measured in the different test conditions. Most interesting in Table 9 is the column 'warmest - coldest temp.', presenting the highest minus the lowest temperature. Obviously, temperature distribution is best when 'warmest - coldest' equals zero.

Table 9, steady state temperatures observed during tests.

\begin{tabular}{|c|c|c|c|c|c|c|c|c|c|c|c|c|}
\hline $\begin{array}{l}\text { Test } \\
\text { no. }\end{array}$ & $\begin{array}{l}\text { Tset } \\
{\left[{ }^{\circ} \mathrm{C}\right]}\end{array}$ & $\begin{array}{l}\text { Tamb } \\
{\left[{ }^{\circ} \mathrm{C}\right]}\end{array}$ & $\begin{array}{l}\text { Evap fan } \\
\text { speed }\end{array}$ & $\begin{array}{l}\text { RHset } \\
{[\%]}\end{array}$ & $\begin{array}{l}\text { FAE } \\
{\left[\mathrm{m}^{3} / \mathrm{h}\right]}\end{array}$ & $\begin{array}{l}\text { T-bar } \\
\text { cover }\end{array}$ & $\begin{array}{l}\text { coldest } \\
\text { time- } \\
\text { avg. } \\
\text { temp. } \\
{\left[{ }^{\circ} \mathrm{C}\right]}\end{array}$ & $\begin{array}{l}\text { coldest } \\
\text { sensor }\end{array}$ & $\begin{array}{l}\text { warmest } \\
\text { time-avg. } \\
\text { temp. }\left[{ }^{\circ} \mathrm{C}\right]\end{array}$ & $\begin{array}{l}\text { warmest } \\
\text { sensor }\end{array}$ & $\begin{array}{l}\text { warmest - } \\
\text { coldest } \\
\text { temp. }\left[{ }^{\circ} \mathrm{C}\right]\end{array}$ & $\begin{array}{l}\text { Tret- } \\
\text { Tsup } \\
{\left[{ }^{\circ} \mathrm{C}\right]}\end{array}$ \\
\hline 1. & +5 & +45 & High & OFF & 0 & $\mathrm{No}$ & 5.2 & 9 & 8.0 & 15 & 2.7 & 2.1 \\
\hline 3. & +5 & +45 & $\begin{array}{l}\text { Low } \\
\text { (imposed } \\
\text { by dehum.) }\end{array}$ & 50 & 50 & $\mathrm{No}$ & 4.6 & 9 & 10.0 & 15 & 5.4 & 3.5 \\
\hline 4. & +5 & +45 & Low & OFF & 50 & $\mathrm{No}$ & 5.5 & 5 & 10.2 & 15 & 4.8 & 3.3 \\
\hline 5. & +5 & +45 & Low & OFF & 0 & $\mathrm{No}$ & 5.6 & 9 & 10.2 & 15 & 4.6 & 3.0 \\
\hline 7. & +30 & 0 & High & OFF & 0 & $\mathrm{No}$ & 27.5 & 16 & 30.4 & 4 & 2.8 & -1.3 \\
\hline 9. & +30 & 0 & High & 50 & 0 & $\mathrm{No}$ & 26.5 & 13 & 31.6 & 4 & 5.1 & -1.7 \\
\hline 10. & +30 & 0 & Low & OFF & 0 & $\mathrm{No}$ & 16.8 & 14 & 30.8 & 4 & 14.0 & -1.8 \\
\hline 12. & +5 & +45 & High & OFF & 0 & cover 1 & 5.1 & 2 & 6.9 & 15 & 1.8 & 1.2 \\
\hline 13. & +5 & +45 & High & OFF & 0 & cover 2 & 5.1 & 2 & 6.6 & 3 & 1.4 & 1.2 \\
\hline 15. & +5 & +45 & Low & OFF & 0 & cover 2 & 5.4 & 2 & 8.4 & 3 & 2.9 & 2.6 \\
\hline 16. & +5 & +45 & High & OFF & 0 & cover 3 & 5.1 & 2 & 6.6 & 3 & 1.5 & 1.2 \\
\hline 19. & +5 & +45 & High & OFF & 0 & cover 4 & 5.0 & 2 & 6.7 & 18 & 1.8 & 1.6 \\
\hline 20. & +5 & +45 & Low & OFF & 0 & cover 4 & 5.3 & 2 & 8.2 & 18 & 2.9 & 3.2 \\
\hline
\end{tabular}


Table 10 shows the results of the power off \& recovery tests. Columns 2 till 5 define test conditions, like in Table 9 . Columns 6 and 7 cover the power of test stage. Column 6 shows the most extreme temperature change recorded after 8 hours power off. Column 7 shows which sensor recorded this most extreme temperature. Column $8-10$ present the results collected during the recovery stage. The SECT is determined for every transport volume ATP sensor. Column 8 shows the maximum SECT recorded by the transport volume ATP sensors. Column 9 shows which sensor recorded the slowest SECT. Finally column 10 presents the average SECT recorded by the transport volume ATP sensors.

Table 10, power loss \& recovery test results (all performed at RHset $=$ OFF, and FAE $=0 \mathrm{~m}^{3} / \mathrm{h}$ ).

\begin{tabular}{|c|c|c|c|c|c|c|c|c|c|}
\hline $\begin{array}{l}\text { Test } \\
\text { no. }\end{array}$ & $\begin{array}{l}\text { Tset } \\
{\left[{ }^{\circ} \mathrm{C}\right]}\end{array}$ & $\begin{array}{l}\text { Tamb } \\
{\left[{ }^{\circ} \mathrm{C}\right]}\end{array}$ & $\begin{array}{l}\text { Evap fan } \\
\text { speed }\end{array}$ & $\begin{array}{l}\text { T-bar } \\
\text { cover }\end{array}$ & $\begin{array}{l}\text { most extreme temp. dev. } \\
\text { after } 8 \mathrm{~h} \text {. power off }\left[{ }^{\circ} \mathrm{C}\right]\end{array}$ & $\begin{array}{l}\text { most extreme } \\
\text { sensor }\end{array}$ & $\begin{array}{l}\text { slowest SECT during } \\
\text { recovery [min] }\end{array}$ & $\begin{array}{l}\text { slowest } \\
\text { sensor }\end{array}$ & $\begin{array}{l}\text { average SECT during } \\
\text { recovery [min] }\end{array}$ \\
\hline 2 & +5 & +45 & High & No & 20.0 & 9 & 343 & 18 & 117 \\
\hline 6 & +5 & +45 & Low & $\mathrm{No}$ & 20.2 & 9 & 444 & 18 & 184 \\
\hline 8 & +30 & 0 & High & No & -10.2 & 4 & 160 & 18 & 80 \\
\hline 11 & +30 & 0 & Low & No & -13.0 & 4 & 78 & 10 & 42 \\
\hline 14 & +5 & +45 & High & \begin{tabular}{|l|} 
cover 2 \\
\end{tabular} & 19.6 & 2 & 276 & 18 & 101 \\
\hline 17 & +5 & +45 & High & cover 3 & 19.9 & 2 & 211 & 18 & 97 \\
\hline 18 & +5 & +45 & High & cover 4 & 19.8 & 2 & 323 & 18 & 106 \\
\hline
\end{tabular}

For ease of mutual comparison of the floor covers Table 11 summarizes the test results concerning the four floor covers. The information in Table 11 is nothing but another way of presenting information provided in Table 9 and Table 10 already.

Table 11 , summary of floor cover tests at Tset $=+5{ }^{\circ} \mathrm{C}$, Tamb $=+45^{\circ} \mathrm{C}$ and high speed evaporator fans.

\begin{tabular}{|c|c|c|c|c|c|}
\hline $\begin{array}{l}\text { T-bar } \\
\text { cover }\end{array}$ & $\begin{array}{l}\text { test } \\
\text { no. }\end{array}$ & $\begin{array}{l}\text { warmest - coldest steady state } \\
\text { temperature }\left[{ }^{\circ} \mathrm{C}\right]\end{array}$ & $\begin{array}{l}\text { most extreme temp. dev. after } 8 \mathrm{~h} \text {. } \\
\text { power off }\left[{ }^{\circ} \mathrm{C}\right]\end{array}$ & $\begin{array}{l}\text { slowest SECT during } \\
\text { recovery [min] }\end{array}$ & $\begin{array}{l}\text { average SECT during } \\
\text { recovery [min] }\end{array}$ \\
\hline $\mathrm{No}$ & 1,2 & 2.7 & 20.0 & 343 & 117 \\
\hline cover 1 & $12,-$ & 1.8 & - & - & - \\
\hline cover 2 & 13,14 & 1.4 & 19.6 & 276 & 101 \\
\hline cover 3 & 16,17 & 1.5 & 19.9 & 211 & 97 \\
\hline cover 4 & 19,18 & 1.8 & 19.8 & 323 & 106 \\
\hline
\end{tabular}


Observations in Table 9, Table 10 and Table 11:

1. Halving the evaporator fan speed nearly doubles the temperature spread from $2.7^{\circ} \mathrm{C}$ to 4.6 ${ }^{\circ} \mathrm{C}$ : compare 'warmest - coldest temp.' for test 1 and 4 in Table 9.

2. Entering an $\mathrm{RH}$ set point has an adverse effect on temperature: it increases the difference 'warmest - coldest' temperature from $2.7^{\circ} \mathrm{C}$ (test 1 in Table 9) to $5.4{ }^{\circ} \mathrm{C}$ (test 3 in Table 9). In heating mode the effect is marginally less strong: compare 'warmest - coldest temp.' for test 7 and 9 in Table 9.

3. Activating dehumidification in cooling mode has a more detrimental effect than only halving the evaporator fan speed: compare test 1, 3 and 4 in Table 9.

4. Switching the dehumidification mode on increases the temperature spread inside the container from 2.7 to $5.4^{\circ} \mathrm{C}$ at Tset $=+5^{\circ} \mathrm{C}$ (compare tests 1 and 3 in Table 9) and from 2.8 to $5.1^{\circ} \mathrm{C}$ at Tset $=+30^{\circ} \mathrm{C}$ (compare tests 7 and 9 in Table 9).

5. In heating mode, at high speed evaporator fans, the temperature spread gets bigger than in cooling mode: compare test 1 and 7 in Table 9 . In test 1 (cooling mode) an abs(Tamb-Tset) of $40^{\circ} \mathrm{C}$ causes a temperature spread of $2.7^{\circ} \mathrm{C}$, while in test 7 a smaller abs(Tamb-Tset) of $30{ }^{\circ} \mathrm{C}$ causes a larger temperature spread of $2.8^{\circ} \mathrm{C}$.

6. In heating mode, at low speed evaporator fans, the temperature spread gets much bigger than in cooling mode: compare test 4 and 10 in Table 9 . In test 4 (cooling mode) an abs(TambTset) of $40{ }^{\circ} \mathrm{C}$ causes a temperature spread of $4.8^{\circ} \mathrm{C}$, while in test 10 a smaller abs(TambTset) of $30^{\circ} \mathrm{C}$ causes a larger temperature spread of as much as $14.0^{\circ} \mathrm{C}$.

7. All three floor covers improve steady state temperatures: compare test 1 with tests $12,13,16$, and 19 (Table 11).

8. Amongst the floor covers cover 3 yields the smallest steady state temperature spread 'warmest - coldest': mutually compare tests $12,13,16$, and 19 (Table 11).

9. Covers 2 and 3 outperform covers 1 and 4 . In terms of steady state temperatures cover 2 is marginally better than cover 3. Cover 3 is superior in terms of SECT: compare both the slowest SECT and the average SECT for tests 14, 17 and 18 in (Table 11).

10. Cover 3 reduces the temperature difference between warmest and coldest measurement location in the transport volume from 2.7 to $1.5^{\circ} \mathrm{C}$, i.e. by nearly $50 \%$ (compare tests 1 and 16 in Table 11) 


\section{Discussion}

Maersk Line's default control mode, Quest II, has been omitted from the test program. The reason is twofold. Firstly Quest II automatically switches evaporator fan speeds based on estimated heat load, hence evaporator fan speed during the tests is ill-defined. Secondly, in these test conditions with large differences between ambient temperature and set point Quest II is programmed to call upon high speed evaporator fans and hence yield results virtually identical to those achieved with control mode HIGH.

In the tests floor cover 3 clearly outperformed floor covers 1 and 4, both in terms of steady state temperature and in terms of rate of temperature pulldown (SECT). The difference between floor cover 2 and 3 is less pronounced. The steady state temperature gradient in case of floor cover 3 is marginally larger than in case of floor cover 2, but the SECT of floor cover 3 is distinctly better than the SECT of floor cover 2. Moreover cover 3 is probably the easiest cover to produce. One should be aware this concerns a load with zero autonomous heat production. Moreover care must be taken in translating these results to the case of not properly precooled cargo. In the test there were hardly any sensors inside the cargo. Of special concern is the temperature pulldown of cartons in the lower tiers of pallets 1 and 2 when using cover 3 , as the cover seems to block most of the air flow in that area.

The first products that are anticipated to benefit from this type of cover: high value temperaturesensitive products with little or no autonomous heat production, which are properly precooled. Some products likely to meet this description are: pharmaceuticals, chilled meat, grapes, kiwi fruit.

Could proper stowing of well-designed pallets and cartons achieve a temperature distribution as uniform as the floor cover? Possibly, but proper stowing is no sinecure. On the contrary, proper placing of the floor cover is much less prone to human errors. The floor cover makes the guidance of air towards the door-end insensitive to the way the pallets are stowed.

In many containers the connection between baffle plate and T-bar is imperfect. The idea of a Tbar cover was not meant to address this topic, but it can do so indeed. By just extending the Tbar cover till well on the baffle plate the cover makes the air flow distribution robust to imperfections in the connection between T-bar and baffle plate.

Due to time limitations none of T-bar covers has been tested in heating mode. What will the effect of T-bar covers be in heating mode? Without T-bar cover heating mode yields larger temperature gradients than cooling mode (compare tests 1 and 7 in Table 9). This is because warm air rises due to natural convection. Therefore in heating mode more air escapes from the opening at the top of T-bars before reaching the door-end. Hence, without cover the air flow rate at the door-end in heating mode is even less than in cooling mode. The air flow distribution with T-bar covers is much less affected by natural convection, because the T-bars simply have much less opening at the top. Therefore it is to be expected that the positive effect of T-bar covers in heating mode is even stronger than in cooling mode. 
All tests were than at $50 \mathrm{~Hz} / 400 \mathrm{~V}$ power supply, while on board of container vessels the power supply is $60 \mathrm{~Hz} / 460 \mathrm{~V}$. Hence a natural question is what these test results mean to the 60 $\mathrm{Hz}$ power supply situation. At $60 \mathrm{~Hz}$ heating and cooling capacities are higher and evaporator fan speed will rise by approx. 20\%. During these tests heating and cooling capacity are not the limiting factors. The main difference is caused by the $20 \%$ evaporator fan speed increase. $20 \%$ fan speed increase yields a little less than $20 \%$ flow rate increase. In steady state the heat ingress into the container is removed by the air circulating inside the container. (Flow rate) * (temperature difference) is a dominant factor in heat transport phenomena in reefer containers. The heat ingress into the container is independent of evaporator fan speed. Hence the authors expect the nearly $20 \%$ higher flow rate at $60 \mathrm{~Hz}$, as compared to $50 \mathrm{~Hz}$, to cause a nearly $20 \%$ smaller temperature gradient. The authors have no access to measurement data to verified/falsify this expectation.

A concern is whether T-bar floor covers are strong enough to stand the weight and manoeuvring of heavy forklift trucks on the T-bars. All stuffing and unstuffing during the test program has been done with light equipment: $52 \mathrm{~kg}$ pallets, manoeuvred with a manual pallet jacks (Fig. 24). Therefore after completion of the test program, during unstuffing at MSD Haarlem, a heavy forklift truck carrying a load of only empty cartons (52 kg), did some manoeuvring on floor cover 4. The forklift truck did not damage the floor cover. This is an encouraging sign. Of course this does not guarantee that the material is sufficiently strong to stand the stuffing with heavy fruit pallets in situations with less careful forklift operation. Therefore it is recommended to investigate whether the floor cover can be manufactured of cheaper and/or more robust material, before the use of floor covers is going to be promoted

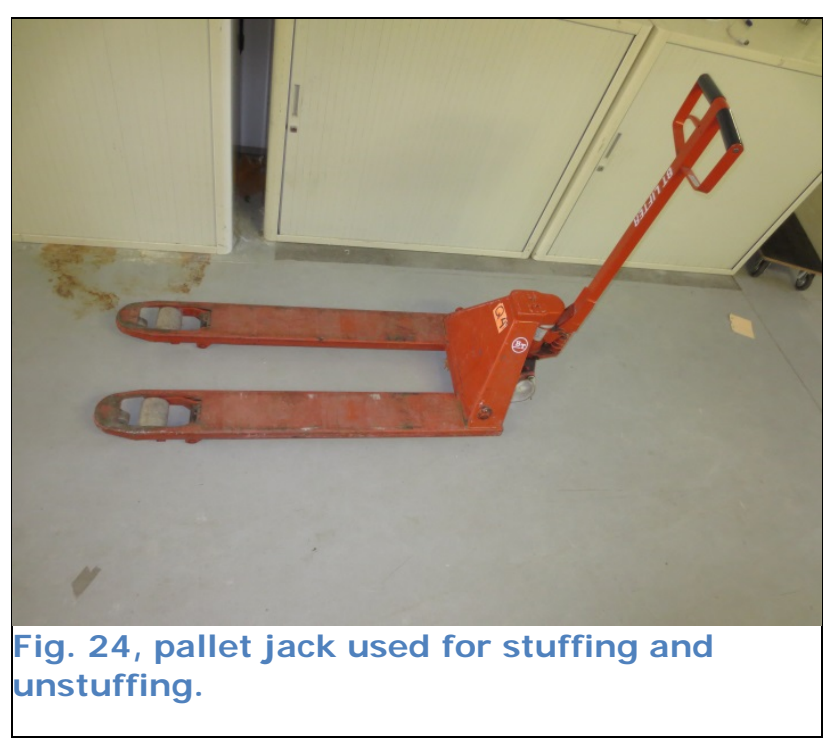
actively.

Possible objections against the use of T-bar covers are: after unstuffing the cover is waste material and someone needs to take care of it, installing the cover takes time and effort, the cover will cost something. In this stage it is unclear in which shipments these drawbacks outweigh the advantage of improved temperature management.

From a merely statistical point of view the basis for conclusions is weak: the data consists of a single series of test conditions with no duplicates at all. Yet there are reasons to be confident. One reason to be confident is that the results correspond with theoretical insights: e.g. reducing evaporator fan speed can only increase temperature differences, and that's what was observed. And also the covering of parts of the floor at the unit-end: it forces more supply air towards the 
door-end and can therefore only bring door-end temperatures closer to supply air temperature, and that's what was observed. It is known that the direct contact between container wall and cartons has a significant impact on carton temperatures. During container loading close attention was paid to avoid this direct contact, but this process is prone to human inaccuracies and hence a known potential source of inaccuracies in the results. In theory there could be something peculiar about the single test container used, but that's unlikely because it was a standard reefer container, of only 6 months old, had no visible damages, and passed PTI just prior to start of the experiments. Altogether we have confidence in the results, but it would be good to repeat the experiments. If it can be organised practically, then it is most effective to those repetitions on a slightly large scale in real transports. 


\section{Conclusions}

1. The best of the four tested T-bar covers is T-bar cover 3 (Fig. 15). It reduces the temperature difference between warmest and coldest measurement location in the transport volume by nearly $50 \%$, and also accelerates temperature recovery after a power off period.

2. Reducing the evaporator fan speed from high to low nearly doubles the temperature difference between warmest and coldest location in the transport volume.

3. Activating dehumidification approximately doubles the temperature difference between warmest and coldest location in the transport volume.

4. In heating mode temperature differences are distinctly larger than in cooling mode. 


\section{Recommendations}

It is recommended to follow up on the positive results of the floor cover tests. Natural chronological steps are:

1. Do some real transport tests with floor cover 3, and possibly cover 2. Parameters to be recorded during those tests are primarily cargo temperatures, but also the cover's resilience to the forces exerted by forklift trucks during stuffing.

2. If the field test results are positive then investigate how a robust, possibly reusable, cover can be produced at low cost. This may require expertise on material technology and manufacturing processes.

3. Decide on where and how to make these floor covers available to Maersk Line customers. 


\section{References}

Anonymous (no year). Hamburg Süd reefer guide.

Brosnan T., Sun D. (2001). Precooling techniques and applications for horticultural products - a review. Int. J. Refrig., 24, pp. 154-170.

Cronje P., Aunstrup S., Bosman J., Norrefeldt V., Sibiya G. (2015). Ambient loading of citrus fruit to cold sterilization markets - 2015 experiments.

Defraeye T., Nicolai B., Kirkman W., Moore S., Niekerk S. Van, Verboven P., Cronje P. (2016). Integral performance evaluation of the fresh-produce cold chain: A case study for ambient loading of citrus in refrigerated containers. Postharvest Biology and Technology. 112, pp. 1 13. Doi 10.1016.

Dodd M.C., Worthington-Smith P. (2006). Managing airflow in reefer containers benefits fruit quality. IIR-IRHACE, Auckland.

Elíasson S., Margeirsson B., Arason S. (2013). Improved reefer container for fresh fish. Matís Icelandic Food and Biotech R\&D report no. 01-13. ISSN1670-7192.

Haan H. De (no year). De Beer's consolidated manual on the transportation of perishable cargo in reefer containers.

Jamal O. R., Young S. M., Love R. J., Ferrua M. J., East A. R. (2015). Exploring a new heterogeneity index to quantify the variation of cooling rates within systems that undergo the forced-air cooling process. In proc. of ICR2015, Yokohama, Japan.

Lawton A.R. (1995). Controlling the temperature of cargo in a container. UK patent GB 2282873.

Lawton A.R. (1999). The splitter board system for improving temperature distribution in ISO containers. Vol. IV (paper 446) in proc. of ICR1999, Sydney, Australia.

Montsma M., Staal M., Lukasse L. (2011). Optimizing shipment of lily bulbs in 40ft reefer containers. Wageningen UR Food \& Biobased Research report no. 1246.

Norrefeldt V. (2015a). Suggestions for floor cover to Leo's trials - v3. Pdf-formatted powerpoint slides.

Norrefeldt V. (2015b). Validation of Maersk Line Reefer Simulation Model - orange and mandarin in supervent, IFCO and open top. Fraunhofer IBP report EER-004/2015/956. 


\section{Acknowledgements}

We are grateful to Maersk Line for financial support of the reefer temperature distribution project. We thank MSD, represented by Dr. Erik van Asselt, for making a dummy load available and for the professional input both in defining the test plan and in the data analysis. We thank Maersk Line, represented by Mr. Steen Aunstrup, for the pleasant cooperation throughout the project. 